\title{
NOTAS PARA UNA REFLEXIÓN SOBRE EL CRISTOCENTRISMO Y LA DEVOCIÓN MEDIEVAL A LA PASIÓN Y PARA SU ESTUDIO EN EL MEDIO RURAL CASTELLANO*
}

\author{
POR \\ RAQUEL TORRES JIMÉNEZ \\ Profesora de Historia Medieval, Universidad de Castilla-La Mancha, Ciudad Real
}

\section{RESUMEN}

Este trabajo propone una reflexión metodológica sobre la devoción medieval a Jesucristo y, en especial, la tributada a Cristo doloroso y su Pasión. Analiza de forma crítica los rasgos de la espiritualidad supuestamente centrada en la humanidad de Cristo entre los siglos XI y XIII y hace hincapié en la complejidad de la piedad patética de los dos siglos siguientes. Por último, plantea una vía de estudio sobre el alcance de este tipo de devoción en un área de observación concreta, un espacio rural castellano al final de la Edad Media (el Campo de Calatrava), a modo de contribución al conocimiento de la religiosidad del pueblo.

PALABRAS ClAVE: Religiosidad popular medieval, Metodología de la historia religiosa, Devoción a Cristo y a su Pasión, Castilla rural, señorío de la Orden de Calatrava.

\begin{abstract}
This study presents a methodological reflection on medieval devotion to Jesus Christ, especially to Christ's sufferings in his Passion. It critically analyses the characteristics of spirituality between the $11^{\text {th }}$ and $13^{\text {th }}$ centuries, which supposedly focused on Christ's humanity. We also emphasize the complexity of the pathetic piety of the next two centuries. Finally we propose an approach to the profile of this type of devotion in a specific area of research, a Castilian rural
\end{abstract}

* Este trabajo se inscribe en el Proyecto «La implantación de la sociedad cristiana en el sur de España: Monarquía, Iglesia y nobleza en el antiguo Reino de Toledo (siglos XII-XV)», HUM200507240-C02-02, financiado por la Dirección General de Investigación del MEC. 
territory at the end of the Middle Ages (Campo de Calatrava), as a contribution to people's religiousness knowledge.

KEY WORDS: Medieval people's religiousness, Methodology of religious history, Devotion to Jesus Christ and his Passion, Castilian rural territory, Lordship of the Order of Calatrava.

Parece indudable que, en todo el Occidente europeo, la devoción a Cristo en su Pasión fue una tendencia creciente en la religiosidad de los siglos XIV y XV. Pero esta propensión devota se integra en un periodo mucho más amplio.

De un lado, se alarga por su final —en un contexto postridentino- y hace eclosión en el auge que tuvieron entre los siglos XVI y XVIII tanto las variadas dramatizaciones de Pasión ${ }^{1}$ como las cofradías de Semana Santa o pasionistas con sus diversas expresiones, incluida la autoflagelación procesional. En general, este tipo de cofradías no existe antes de 1520 ó 1525 en Castilla, León o Andalucía, aunque diversos elementos suyos se conozcan desde mediados del siglo XV en otras hermandades «de la Preciosa Sangre de Cristo» ${ }^{2}$.

Y, en el extremo cronológico contrario, la citada corriente de piedad bajomedieval centrada en Cristo doloroso se ve precedida por una proclividad especial de la devoción y la teología a la humanidad de Jesucristo ya apreciable, según se admite, desde el siglo $\mathrm{XI}^{3}$.

En torno a estas cuestiones se quiere proponer una reflexión metodológica articulada en dos direcciones. En primer lugar, consideraremos la orientación cristocéntrica de la piedad propia de los siglos XI, XII y XIII desde un ángulo crítico en cuanto a la centralidad de la humanidad de Cristo. Todo apunta a la existencia de una enorme complejidad en los perfiles de la religiosidad aparentemente más definidos (la piedad hacia la humanidad y la Pasión de Cristo en este caso). En segundo lugar, sobre el fondo del auge pasionista de los siglos $\mathrm{XIV}$ y XV, tan propio de las claves religiosas de este tiempo, trataremos de ana-

${ }^{1}$ Como el entierro de Cristo en Portugal y en España; por ejemplo, en el convento de las Descalzas Reales de Madrid, fundado por la hija de Carlos V. J. L. GonZÁlez Novalín, «Religiosidad y reforma del pueblo cristiano», La Iglesia en la España de los siglos XV y XVI: Historia de la Iglesia en España, III-1. ${ }^{\circ}$, R. García VillosladA, director, Madrid, Biblioteca de Autores Cristianos (BAC), 1980, p. 376.

2 J. SÁnchez Herrero, «Pasión y sangre. En torno al origen de las cofradías de Semana Santa hispana», L'enseignement religieux dans la Couronne de Castille. Incidences spirituelles et sociales (XIII $-X V^{e}$ siècle), D. Baloup, éditeur, Madrid, Collection de la Casa de Velázquez (79), 2003, p. 125.

3 «No puede haber una verdadera contemplación de la Pasión y Muerte de Cristo mientras que la teología y la devoción no se inclinen por la humanidad de Cristo... mientras no estemos plenamente convencidos de que Cristo es un hombre como cualquiera de nosotros».- J. SÁNCHEZ HerRERO, «Piedad y artes plásticas. La devoción a la preciosa Sangre de Cristo durante los siglos XIII a los primeros años del XVI y su influencia en las manifestaciones artísticas», Piedade popular, Lisboa, 1999, p. 411. 
lizar el alcance de la devoción a Cristo doliente en los siglos bajomedievales en un área concreta de observación, en la medida en que cabe rastrear sus indicios. Se trata de abrir una ventana a la vida cristiana común de laicos y clérigos en el marco sobre todo parroquial. Es un área rural y, por ello, difícil de conocer. Este análisis puede tomarse como un ejemplo metodológico de la precariedad de la información al respecto, en contraste con la riqueza de datos que pueden aportar los medios urbanos para las celebraciones litúrgicas o extralitúrgicas y su vivencia laica, y también lejos de las interesantes perspectivas que se abren al examinar los escritos de espiritualidad propios del clero o, en general, de personas muy cultivadas, singularmente los textos místicos masculinos y femeninos. En este caso, la indagación ha de ceñirse al periodo terminal del Medievo, el que ciertas fuentes descubren: se trata de las tierras del Campo de Calatrava. La zona tiene un perfil administrativo y jurisdiccional bien definido, pero ello no llega a conferirle rasgos identitarios singulares en el terreno espiritual; es decir: la vida religiosa de su clero y su laicado en este aspecto de la piedad pasionista, como en otros, puede tomarse como una muestra de la religiosidad de la época en el medio rural de Castilla, o más bien, de la parte de aquella que emerge en las fuentes.

\section{EL LUGAR DE LA PIEDAD CRISTOCÉNTRICA Y EVANGÉLICA EN LAS SENSIBILIDADES RELIGIOSAS ENTRE LOS SIGLOS XI Y XIII}

Se viene admitiendo que en la plena Edad Media un cristocentrismo dominante en la espiritualidad occidental colocó en primer plano el descubrimiento de Jesús en su existencia terrena. Esta nueva orientación de la sensibilidad religiosa, la iconografía e, incluso, la liturgia, es comúnmente señalada en las obras generales sobre religiosidad medieval ${ }^{4}$ de forma explícita o incidiendo en mutaciones ligadas a la vida urbana y a la predicación, sin necesidad de recurrir a figuras o movimientos concretos, por lo demás tan representativos, como San Bernardo, San Francisco de Asís y el franciscanismo, etc. El periodo ha sido definido como «la edad de Cristo»5. Pero conviene profundizar en el significa-

\footnotetext{
${ }^{4}$ Entre otras: É. Delaruelle, La piété populaire au Moyen Âge, Torino, 1980; R. MANSELLI, La religion populaire au Moyen Àge. Problèmes de méthode et d'histoire, Montréal, 1975; J. F. RIVERA RECIO, «Espiritualidad popular medieval», Historia de la Espiritualidad, A, I, Barcelona, 1969; Histoire du Christianisme des origines à nos jours, V: Apogée de la papauté et expansion de la chrétienté (1054-1274), y VI: Un temps d'épreuves (1274-1449), A. VAUCHEZ, dirécteur, París, 1993 y 1990; Historia del cristianismo, 2: El mundo medieval, E. Mitre FERNÁNDEZ, coordinador, Madrid-Granada 2004; J. ChÉLInI, Histoire religieuse de l'Occident Médieval, París 1999 (reed. de 1968); J. PAul, Le christianisme occidental au Moyen Âge, IVe-XVe siècles, París 2004. F. J. Fernández CONDE, La religiosidad medieval en España: Alta Edad Media (s. VII-X), Oviedo, 2000; ID., La religiosidad medieval en España: Plena Edad Media (s. XI-XIII), Gijón, 2005.

5 A. VaucheZ, La espiritualidad del Occidente Medieval (siglos VIII-XII), Madrid, 1985, p. 72.
} 
do de esta espiritualidad —en el sentido acuñado por Vauchez ${ }^{6}$ — para aquilatar el alcance del cristocentrismo que se habría impuesto entonces en contraste con la piedad altomedieval.

No se trata de reproducir el elenco de manifestaciones de esa forma de piedad, sino de analizar su grado de novedad en tanto que muestra del supuesto deslizamiento del centro de gravedad piadoso desde el Padre Creador y Juez hacia el Hijo hecho hombre; del Antiguo al Nuevo Testamento. En suma, ampliando el análisis al más vasto campo de las mentalidades, se trataría también de comprobar si se están transmutando las nociones sobre el hombre y el cosmos. De un lado, si está cambiando la concepción antropológica: el hombre no sería sólo la criatura de Dios que le debe el ser y la salvación del pecado por los méritos de Cristo, sino el «hijo», «coheredero con Cristo» ${ }^{7}$, el hermano de Cristo a quien, como Hombre, puede imitar en su testimonio de amor. Y otra consecuencia del nuevo cristocentrismo podría ser el cambio en la percepción del mundo. Es decir: de un mundo sentido como resultado y hechura de un Dios Creador que lo señorea, y un mundo que se encamina a la consumación de los tiempos metahistóricos bajo el reinado del Hijo glorioso, al mundo como campo de acción del propio Dios encarnado en la humanidad, Jesucristo; humanidad a la que Él sigue nutriendo de vida divina con su Espíritu pero con la que comparte naturaleza y sufrimiento, y a la cual, por la redención, incorpora en su tarea transformadora desde dentro de la historia. Este cambio no implicaría una imposible negación de Dios, y ni siquiera una reivindicación de autonomía de lo terrenal, pero sí, dentro de la «hegemonía de lo religioso» ${ }^{8}$, una visión positiva de la acción humana en la tierra con consecuencias en la moral o la acción política, lo que finalmente conduciría desde el siglo XIV a fenómenos tan diversos como la liberación de los Estados respecto a la tutela pontificia o el auge de la interiorización espiritual.

$\mathrm{Al}$ servicio de la pregunta sobre el alcance del cristocentrismo plenomedieval, examinamos a continuación tres campos de la realidad religiosa, que en

\footnotetext{
${ }^{6}$ La espiritualidad no será sólo la dimensión religiosa de la vida interior con unas pautas codificadas, sino el conjunto de relaciones entre los aspectos del misterio cristiano y las prácticas más valorados en una época: en suma, el modo de interpretar y vivir el mensaje cristiano y también, para cada periodo, la concepción de Dios y de las relaciones del hombre con Dios; hablar en plural de «espiritualidades» que se superponen es más adecuado. A. VAUCHEZ, La espiritualidad del Occidente Medieval (siglos VIII-XII), pp. 9-11.

7 «... hijos de Dios, y si hijos, también herederos: herederos de Dios y coherederos de Cristo», Romanos 8, 16-17. Gálatas 4, 7. Todas las citas bíblicas se ofrecen según la Biblia de Jerusalén, edición española, J. A. UBIETA LóPEZ, director, Desclée de Brower, Bilbao, 2001, nueva edición revisada y aumentada.

${ }^{8}$ Cfr. H. Martin, Mentalités Médiévales. XI $I^{e} X V^{e}$ siècle, París, 2004 (2. ${ }^{a}$ reimpr. de 2. ${ }^{a}$ ed. corregida), pp. 16 ss. en especial. A. GuRIÉVICH, Las categorías de la cultura medieval, Madrid, 1990, pp. 23-50.
} 
realidad se interrelacionan: a) el terreno clerical erudito; b) el de la piedad popular o laica en sus expresiones más exclusivas; y c) un ámbito de intersección entre religiosidad popular y clerical materializado tanto en movimientos seglares de perfección como en formas de vida consagrada ${ }^{9}$, surgidos del mismo tronco espiritual generador de demandas religiosas.

a) El ámbito clerical erudito, que en realidad subyace o influye tarde o temprano en la religiosidad popular de la cual, a su vez, recibe impulsos, no es ahora el más relevante. Recordemos sólo dos datos.

Primero, «Cristo fue colocado en el corazón de la interpretación de las Sagradas Escrituras» ${ }^{10}$ : retomando la tradición patrística, se intensificó la lectura del Antiguo Testamento en clave de prefiguración de la vida de Jesús: es comparado con Adán, Isaac, Jonás, David y la serpiente de bronce alzada por Moisés; es el Varón de Dolores de Isaías; la esposa adúltera con la que dialoga Yahvé a través de Oseas es alegoría no sólo del pueblo escogido sino también de la Iglesia, etc.

Y segundo, la producción teológica acusaba la preocupación por la figura de Cristo y su encarnación. Esto ocurre ya desde el final del siglo XI, y el paradigma es el Cur Deus homo? (1098) de San Anselmo de Canterbury.

Ahora bien, debe reconocerse que el primer dato se limita a avalar un esquema coherente del plan misterioso de Dios sobre la redención del género humano; y de otro lado, el benedictino abad de Bec y arzobispo de Canterbury se movía más bien en las coordenadas de la lógica, sin metafísica, y desde ahí meditaba — según la vía racional dialéctica — sobre la necesaria existencia de Dios y lo inevitable de la encarnación divina para restaurar el orden del universo y la naturaleza humana caída ${ }^{11}$. Incluso admitiendo la novedad de la reflexión de San Anselmo sobre Cristo, sin embargo la cristología de San Bernardo, después, supondría un retroceso ${ }^{12}$ : su consideración de la Pasión no consistiría en

9 Es una división aleatoria de campos de indagación. Su delimitación dentro de la realidad eclesiástica y religiosa es difícil. Hay diferencia clara entre dos grandes campos: el organizativo y el de la religiosidad. Pero el último encierra muchas posibilidades. Hemos optado por la sistematización señalada, pero pueden considerarse otras. Así, Iluminado Sanz Sancho, cuando se refiere a la «comprensión del objeto» y propone una tipificación de análisis temáticos del hecho eclesial histórico, al ceñirse a la religiosidad distingue cinco categorías y las dos primeras son significativas: separa las propuestas religiosas de la autoridad eclesial, de un lado, de la vitalidad religiosa del pueblo y sus realizaciones, de otro; y en la última incluye tanto la vida consagrada como los cultos populares, fiestas, cofradías, etc.-I. SANZ SANCHO, «Para el estudio de la Iglesia medieval castellana», Estudios eclesiásticos. Revista teológica de investigación e información, 73 (1998), 61-77, en especial 84-85. Es decir, unifica en la segunda categoría («vitalidad religiosa del pueblo») lo que nosotros separamos como $a$ ) expresiones de la religiosidad popular y $b$ ) ámbito de intersección entre lo clerical/culto y lo popular.

10 J. SÁnchez Herrero, Historia de la Iglesia, II: Edad Media, Madrid, BAC, 2005, p. 324.

11 M. A. Ladero Quesada, Historia Universal. Edad Media, Madrid, 2001 (1. a ed., 1987), p. 514.

12 J. SÁnCHEZ HerRero, «Pasión y sangre. En torno al origen de las cofradías de Semana Santa», p. 126. 
la meditación entrañable de los sentimientos y sufrimientos de Jesús, sino más bien en la reflexión sobre sus efectos; es decir, la salvación de la humanidad ${ }^{13}$. Estaría más cerca del Pantocrátor victorioso o de ese crucificado que incluso en la cruz lleva una aureola de triunfo, que del patetismo posterior.

b) ¿Qué ocurría entre el común de los cristianos, aquellos a quienes se pedía básicamente cumplir los mandamientos y conocer el Credo y las oraciones más elementales, aquellos que ni se integraban en movimientos heterodoxos ni abandonaban su forma de vida ordinaria? ¿Se hacían eco de esas reflexiones sobre la encarnación y sobre la centralidad decisiva de Cristo en la historia de la salvación?

Son preguntas de respuesta incierta; pero las elaboradas propuestas clericales llegaban sólo muy paulatinamente a los fieles que, habitualmente, permanecían aferrados a las ideas más sencillas. Además, se propendía a identificar las nociones doctrinales con sus consecuencias morales en las que se ponía todo el acento, o se diluían las primeras en las segundas. ¿Cómo se transmitía la teología cristológica? Para salvarse, se exigía al fiel estar instruido en la fe y las costumbres, como repiten los sínodos y concilios hispanos siguiendo al Concilio Nacional de Valladolid de $1322^{14}$; ambas son la clave de su vida ${ }^{15}$ («Segund que dise sant Agostyn, toda la fasienda de los cristianos esta en dos cosas: en fe e en costunbre» ${ }^{16}$ ). Pero no parece que la jerarquía pusiera mayor interés en afinar la instrucción. Procuró diversificar los medios para transmitir la doctrina: al final del siglo XV, a la tabla y a la predicación se añadirá la catequesis y se ampliará el contenido ${ }^{17}$. Pero no se pretendía su explicación ni su profundización. De Cristo se debía conocer los siete artículos de fe sobre su divinidad y los siete sobre su humanidad ${ }^{18}$. La predicación, tan fomentada desde el Concilio IV

13 J. LECLERCQ, San Bernardo, monje y profeta, Madrid, 1990, p. 92.

14 «Ideoque volentes aeternam salutem adipisci, oportet de Fide et moribus esse eruditum».Concilio Prov. Aranda, 5-XII-1473, 7, en J. SÁnchez HERrero, Concilios provinciales y sínodos toledanos de los siglos XIV y XV. La religiosidad cristiana del clero y pueblo, La Laguna, 1976, Apénd., p. 285 .

15 «Summa totius discipline christiane, ut ait augustinus, est in fide et moribus».- -Sínodo diocesano de Toledo, 25-V-1323, 1, en J. SÁNCHEZ Herrero, Concilios provinciales y sínodos toledanos de los siglos XIV y XV, Apénd., p. 174. Se repite en el Libro de las Constituciones Sinodales de don Blas Fernández de Toledo, 1, publicadas en el Sínodo Diocesano de Toledo, 3-V-1356. Ibidem, p. 224.

16 Inicio de la serie de constituciones sinodales de Cartagena-Murcia a partir de 1323, con una recepción diáfana del Concilio legatino de Valladolid del año anterior. Publ. I. SANZ SANCHo, Constituciones sinodales de la Diócesis de Cartagena de 1323 a 1409, Universidad de Murcia, 2002, p. 50.

17 El núcleo básico lo habían integrado los 14 artículos de la fe (credo), los sacramentos, los 10 mandamientos, las virtudes teologales y cardinales y los 7 pecados capitales; ahora se añaden: los 7 dones del Espíritu Santo, las obras de misericordia y los mandamientos de la Iglesia.

18 Los de la humanidad, según el bello texto romance del Sínodo de Cartagena de 1323: «El primero es que el Fijo de Dios fue conçebido del Espiritu Santo. El segundo es que nasçio de santa Maria, fincando ella Virgen. El terçero es que rresçibio por nos muerte e pasion en poder de Pilato. El quarto

Hispania Sacra, LVIII

118, julio-diciembre 2006, 449-487, ISSN: 0018-215-X 
de Letrán, 10 (1215), solía tener un fin moral. Y las centradas en la Pasión, el Jueves Santo o el día de Pascua, «respondían más al género panegírico y de exaltación de la festividad que a un plan trazado, o siquiera intentado, de formación de la fe» ${ }^{19}$.

Si el panorama descrito es el posterior al Concilio IV de Letrán que tanto estimuló los medios de difusión de la fe, con mayor razón se reconocerá la dificultad de que entre los siglos XI y XIII los pormenores y novedades de la meditación especulativa sobre la redención y la Pasión alcanzaran a los cristianos sencillos. Desde luego, el mensaje teológico tendía a simplificarse, y aún a deformarse, en el proceso de interpretación y luego transmisión de las normas: fácilmente lo anecdótico pasaba a primer plano a costa del sentido genuino de aquéllas, con tal de reconducir las conductas hacia el modelo moral cristiano ${ }^{20}$.

La transmisión de las propuestas teológicas más elaboradas no llegaba a producirse o éstas se desvirtuaban. Pero por otra parte, no se insiste lo suficiente en lo contrario: la influencia de la religiosidad popular medieval en las elaboraciones cultas; no tanto en las doctrinales pero sí en las morales y en las disciplinares. Piénsese en la permeabilidad de la liturgia a los usos populares o en cómo se imponían la casuística y las excepciones a mandamientos básicos como el descanso dominical. La norma se adaptaba a la realidad.

En todo caso, la indagación sobre la comunicación y transmisión de fuerzas espirituales para explicar cambios de tendencias debe hacerse en campos de es-

es que desçendio en su anima a los infiernos, porque sacase dende a los santos padres, que eran y. El quinto es que rresuçito al terçero dia. El sesto es que a cabo de quarenta dias despues dela Resurreçion subio a los çielos e esta a la diestra parte de Dios Padre. El septimo es que en la fin del mundo verna a judgar los bivos e los muertos e dara a los malos pena perdurable e a los buenos gloria por sienpre jamas».--Inicio de las constituciones sinodales de Cartagena-Murcia desde 1323. Publ. I. SANZ SANCHO, Constituciones sinodales de la Diócesis de Cartagena..., p. 51.

19 I. SANZ SANCHO, «Los sínodos diocesanos medievales cordobeses y la religiosidad del clero y del pueblo», Las fiestas de Sevilla en el siglo XV. Otros estudios. C.E.I.R.A., 2 (Centro de Estudios e Investigación de la Religiosidad Andaluza), Madrid, 1991, p. 385.

20 Así se ve al confrontar las disposiciones sinodales con mandatos similares de los visitadores de la orden de Calatrava hechos a sus dominios. Por ejemplo, los sínodos toledanos del siglo XV se afanan en que el pueblo asista los domingos y fiestas a la misa mayor y no a otra. Para ello prohíben celebrar cualquier misa votiva en esos días. Pues bien, los visitadores calatravos conocen la norma, pero al transmitirla a las iglesias del señorío, introducen una excepción que, en la práctica, acaba con el fin esencial de aquella: permiten las misas votivas, pero sólo una vez que haya terminado «el alçar» de la misa mayor. Legitiman, pues, el solapamiento, la dispersión de los fieles, si es salvaguardada la prelación del rito de la Elevación dela misa mayor. La dimensión comunitaria esencial de la misa mayor dominical-festiva se desvirtúa.-Vid. R. TORRES JiménEZ, «Liturgia y espiritualidad en las parroquias calatravas (siglos XV-XVI)», Las Órdenes Militares en la Península Ibérica, I: Edad Media, R. IzQuierdo Benito y F. RuIz Gómez, coordinadores, Cuenca, 2000, pp. 1087-1116. 
tudio acotados y a partir de fuentes que permitan la comparación, porque la cuestión es compleja, sobre todo según los paradigmas de la sociología de la religión y de la historia de las mentalidades ${ }^{21}$.

Advertidos estos matices, debe admitirse que, en general, entre los cristianos sencillos de los siglos XI al XIII se difundió mucho más que antes la vida de Cristo; un conocimiento derivable a lo devocional aunque ello no signifique forzosamente la identificación piadosa con su vida y pasión. Lo último se aprecia en los grupos de penitentes flagelantes, pero en este periodo son minoritarios; sólo en el siglo XIII aparece alguno en Italia ${ }^{22}$. Recordaremos dos consecuencias de la difusión de la vida de Jesús más extendidas: la eclosión de las peregrinaciones a Tierra Santa y la divulgación de las narraciones sobre su biografía terrenal.

\section{Peregrinaciones a Tierra Santa}

Desde el pleno Medievo los fieles buscaron más masivamente la huella tangible de la vida terrena de Jesús sus reliquias y peregrinando a los Santos Lugares. El homo viator, consciente de su desarraigo del mundo, «peregrino por esencia, por vocación» ${ }^{23}$, penitente y a la vez aventurero, y anhelante de pisar los lugares que recorrió el Señor, converge con el cruzado que peregrina en la forma más arriesgada — tal es el sentido de la llamada de Urbano II- y con los caballeros que atienden hospitalariamente a los peregrinos y garantizan y defienden su acceso a Jerusalén —Órdenes Militares-.

Como derivación de la espiritualidad de la peregrinación, que manifiesta fervor por la humanidad de Cristo y a la vez se nutre de otros ingredientes, debe recordarse el fenómeno de las cruzadas populares, a menudo ligadas

${ }^{21}$ Los emisores y los receptores no son ni inmutables ni uniformes, los canales de comunicación son versátiles y los códigos de los mensajes, interpretables en claves diferentes. Piénsese en lo que tardaban en imponerse en cada Reino las constituciones conciliares generales de la Iglesia; ténganse en cuenta las mediaciones existentes entre la normativa canónica y el clero parroquial rural: estructuras diocesanas, jurisdicciones señoriales interpuestas...; recuérdese que a menudo las costumbres imponían excepciones de hecho a las normas, etc. La importancia de las influencias de abajo a arriba, la complejidad de las interacciones entre religión culta o sabia y fe popular, las transformaciones producidas en las transmisiones de mensajes e imágenes, etc., aplicado todo ello entonces a la liturgia y la espiritualidad, fueron objeto de algunas reflexiones a la luz de las claves aludidas, tomadas de la historia sociológica y de la antropología entre otras, en R. TORRES JIMÉNEZ, «Liturgia y espiritualidad en las parroquias calatravas (siglos XV-XVI)», pp. 1092-1095.

22 Así las fraternidades y grupos de Florencia y de Perugia, desde 1218 (el Ordo de Penitencia, la Gran Devoción) y otros ya al final del siglo XIII, ligados al franciscanismo. J. SÁncheZ HERRERO, «Pasión y sangre. En torno al origen de las cofradías de Semana Santa hispana», pp. 132133.

23 J. LE GofF, «Introducción», El hombre medieval, J. LE GofF, editor, Madrid, 1990, 17. 
con los movimientos heréticos mesiánicos y milenaristas ${ }^{24}$. El peregrino puede integrarse en grupos acaudillados por un propheta, elegidos para protagonizar la última victoria escatológica sobre el Anticristo en la ciudad santa, donde «ya no habrá muerte ni habrá llanto ni gritos ni fatigas, porque el mundo viejo ha pasado» ${ }^{25}$. Una Jerusalén celestial y mesiánica pero a la vez real, y siempre colmada de riquezas, «engalanada como una novia ataviada para su esposo» ${ }^{26}$, la Esposa del Cordero refulgente por la luz de la gloria misma de Dios y perfecta en sus proporciones según la descripción de Ezequiel (caps. 40-48): una nueva tierra prometida donde los escogidos que no han adorado a la Bestia reinarán con Cristo primero por mil años y después eternamente ${ }^{27}$.

Notemos la ambivalencia del cristocentrismo presente en estos fenómenos. De un lado, es rotundamente notorio: coloca a Cristo como el alfa y la omega ${ }^{28}$, y, abrazando una concepción integral del devenir del mundo, implica la creencia en la victoria final del Hijo de Dios hecho hombre en su Parusía o segunda venida triunfante al fin de los tiempos. En ese reinado feliz de mil años junto a Él se cumplirá el plan de Dios: «recapitular en Cristo todas las cosas del cielo y de la tierra ${ }^{29}$. Ahora bien: en realidad, el Cristo encarnado que comparte su suerte con el hombre, se reviste con sus pecados y sufre la humillación de la esclavitud y de la cruz ${ }^{30}$ no es el aceptado en las esperanzas milenaristas. Éste es el Cristo celestial del gran trono blanco ${ }^{31}$, vencedor definitivo de Satanás y su innumerable ejército. Poderoso y terrible, hizo bajar «fuego del cielo que los devoró» ${ }^{32}$

24 N. Cohn, En pos del milenio. Revolucionarios milenaristas y anarquistas místicos de la Edad Media, Madrid 1997 (6. ${ }^{\circ}$ reimpr. de la 3. ${ }^{\circ}$ ed.); M. D. LAMBERT, La herejía medieval. Movimientos populares de los bogomilos a los husitas, Madrid 1986; Milenarismos y milenaristas en la Europa medieval. IX Semana de Estudios Medievales (Nájera, 1998), Logroño, 1999; J. GuAdalaJara MEdina, Las profecías del Anticristo en la Edad Media, Madrid, 1996; E. Mitre FERnÁNDEZ y C. GRANDA, Las grandes herejías de la Europa cristiana (380-1520), Madrid, 1983. Vid. el número dedicado a Las herejías medievales. Estado de la cuestión, I. BAZÁN, editor, en la revista digital Clio \& Crimen 1 (2004): artículos generales de C. GonzÁLEz Mínguez (pp. 19-21) y E. Mitre FernáNDEZ (pp. 23-42) y otros más centrados de A. RUCQUOI, " "No hay mal que por bien no venga": Joaquín de Fiore y las esperanzas milenaristas a fines de la Edad Media» (pp. 217-240), y ÁlvAREZ PALENZUELA («Wyclif y Hus: la reforma heterodoxa»). SÁNCHEZ HERRERO conecta el sentir religioso popular con las herejías milenaristas («Desde el cristianismo sabio a la religiosidad popular...», pp. 301-335).

25 Apocalipsis (Ap.) 21, 4.

26 Ap. 21, 2.

27 Ap. 20, 1-6.

28 Ap. $21,6$.

29 Efesios 1, 10; Colosenses 1, 20.

30 «... siendo de condición divina, no codició el ser igual a Dios sino que se despojó de sí mismo tomando condición de esclavo... se rebajó a sí mismo, haciéndose obediente hasta la muerte y una muerte de cruz», Filipenses 2, 6-8.

31 Ap. 20, 11.

32 Ap. 20, 7-9. 
cuando, soltados por breve tiempo tras los mil años, cercaban el campamento y la ciudad de los santos. El escatologismo, rasgo recurrente de la religiosidad popular ${ }^{33}$, no inclina el sentir del pueblo hacia Jesús encarnado e imitable; al contrario, permanece de espaldas a la clave cristológica de la creencia cristiana en su plena dimensión terrenal y divina a la vez. ¿No estamos en presencian de uno de tantos modos de atenuar la humanidad de Cristo desarrollados en la historia del Cristianismo?

\section{Narraciones de la vida de Cristo}

En esta época los fieles se familiarizaron con la infancia de Jesús y su familia, siempre con María en lugar privilegiado. Por consiguiente, se dice, se difundía el ideal de su imitación. Se ha dado por válido ese razonamiento y se refuerza afirmando que, sin duda, la encarnación aparecía como el hecho capital del cristianismo, con consecuencias tan diversas como el triunfo del fervor mariano desde el siglo XII o la datación del año iniciada el 25 de marzo.

A todo ello contribuían los predicadores y la divulgación de los evangelios, incluidos los apócrifos, muchos de los cuales relataban detalles de la Natividad y la infancia de Jesús. Pero hay que discernir qué relatos apócrifos se divulgaron en el Occidente latino, teniendo en cuenta que un cierto evangelio podía no difundirse íntegro y sí, en cambio, ser muy asumidos elementos suyos en el acervo común. Así, el muy antiguo Protoevangelio de Santiago (anterior al siglo IV) aportó a la tradición detalles como los nombres de los padres de la Virgen, Joaquín y Ana, y sobre la infancia de María, a pesar de ser tempranamente prohibido en Occidente (Decretum Gelasianum, siglo VI). Sus leyendas se difundieron ampliamente mediante otros cauces, sobre todo el misceláneo Evangelio del Pseudo Mateo (siglo VI). Éste fue (para Aurelio de Santos Otero) el gran inspirador del arte medieval, del carolingio Liber de infantia Salvatoris, de la Leyenda Áurea de Jacques de Voragine, y, en suma, el transmisor de narraciones sobre las vidas de María y sus padres, José y Jesús recién nacido y niño ${ }^{34}$. También recoge y difunde buena parte del Evangelio del Pseudo Tomás con sus episodios milagrosos de Jesús entre los cinco y los doce años. Y el compilatorio Evangelio Árabe de la Infancia, posterior al siglo VI y con versiones latinas de los siglos XIII y XIV (nótese bien la cronología) se inspira tanto en el Protoevangelio de Santiago como en el Pseudo Tomás: las palabras de Jesús en la cuna inician el relato de continuos milagros en sus juegos, ocurridos con sus

33 J. SÁNCHEZ HERRERO, «Desde el cristianismo sabio a la religiosidad popular en la Edad Media», Clio \& Crimen, 1 (2004), p. 326.

${ }^{34}$ La dedicación de María al templo en su niñez, la escena del nacimiento con el buey y la mula en una cueva, una serie de portentos rodeando a los tres personajes durante su vida en Nazaret, etc.

Hispania Sacra, LVIII

118, julio-diciembre 2006, 449-487, ISSN: 0018-215-X 
maestros y vecinos, etc. ${ }^{35}$. En Castilla contamos con un poema hagiográfico anónimo escrito en la primera mitad del siglo XIII en lengua vernácula; es el Libro de la infancia y muerte de Jesús, basado en los apócrifos y en los Loores de Nuestra Señora de Berceo ${ }^{36}$.

Ahora bien, no hay que sobredimensionar el significado de la difusión de estos relatos. En un nivel cultivado, la familiarización con los detalles de la infancia de Cristo podía formar parte de una contemplación amorosa del acontecimiento de la encarnación del Verbo en la humildad de la carne humana. Pero no minusvaloremos la posibilidad de que, en el imaginario popular, todos estos pormenores resultaran asimilados a los que las gentes conocían en las vidas de los santos, y que sus aspectos milagrosos fueran captados más por espectadores maravillados que por devotos seguidores del Señor. El gusto por recrearse en el transcurrir terrenal de los milagros y episodios cotidianos de la sagrada familia no implica necesariamente, ni mucho menos, la conciencia del misterio de la encarnación divina con todas sus consecuencias, ni el impulso para una conversión de vida consistente en la imitación del Dios hecho hombre, Cristo encarnado como Señor y centro de la propia vida.

c) Veamos ahora el terreno que definimos como de intersección entre laicado y clero en cuanto a la creación de formas nuevas de vida religiosa. Nos fijamos en los seglares; pero sus búsquedas y su orientación hacia modos originales de vida cristiana los separarían finalmente del ordo laicalis con sus mundanos compromisos familiares y laborales. Aquellas búsquedas desembocarían, particularmente entre las mujeres, en formas de vida consagrada reglada (al final del Medievo las casas de beatas serían reintegradas en órdenes religiosas).

En todo caso, en el pleno Medievo, la propagación de las citadas narraciones apócrifas o evangélicas y la integración en las mentalidades colectivas de las circunstancias de vida del Jesús hombre se producían en un nuevo medio urbano propicio a la difusión de tendencias espirituales. Los laicos formados buscaron modos de perfección compatibles con su estado (cofradías, órdenes terceras, peregrinaciones, ejercicios piadosos) o formas originales de vida consagrada sin estructuración en institutos regulares (begardos, beguinas o beatas) $)^{37}$.

35 A. DE SANTOS OTERo (introd. y versión de los textos originales), Los evangelios apócrifos, Madrid, BAC 2001, pp. 55-191 para los Apócrifos de la Natividad y la Infancia.

36 J. FERNÁNDEZ CONDE, «Religiosidad popular y piedad culta», La Iglesia en la España de los siglos VIII-XIV: Historia de la Iglesia en España, II-2. ${ }^{\circ}$, R. GARCía-VILlOSLADA, director, Madrid, BAC 1982 , p. 356.

37 Es el esquema evolutivo que propone André Vauchez: de la espiritualidad monástica del siglo X, modelo inalcanzable de perfección, a una espiritualidad más adecuada a la vida seglar desde los siglos XI y XII. Es la tesis esencial de su conocido libro La espiritualidad del Occidente Medieval (siglos VIII-XII). 
La vita evangelica, la vita apostolica y la pobreza voluntaria, sustratos de aquellos ideales de reforma de la Iglesia superpuestos desde diferentes registros y asumidos por el pontificado en la Reforma Gregoriana, informaban tanto las nuevas órdenes religiosas mendicantes como, en cierto modo, el eremitismo, o también movimientos heterodoxos como el valdismo o la pataria. Estos últimos se radicalizaban en su rechazo a la jerarquía (corrupción, monopolio de la predicación) y en sus propuestas doctrinales y disciplinares. En el caso de los pobres de Lyon o valdenses, sus conductas implicaban cambios sustanciales en los terrenos sacramental y eclesiológico (protagonismo del laicado a expensas del clero no sólo al predicar, sino en los sacramentos), pero su pauperismo exacerbado y su emulación literal del proceder apostólico respondían a la misma línea de fuerza espiritual que transformó la vida religiosa con formas tan diversas: la búsqueda de una vida más conforme al Evangelio según la pureza originaria de la vida y predicación de Jesús ${ }^{38}$.

Sin embargo, hay que matizar el alcance de esta búsqueda. Es cierto que, como afirma Jacques Paul, hacia el siglo XII «el evangelismo se impuso como una evidencia y desplazó a los demás comportamientos religiosos», y ello generó una transformación de gran alcance en las mentalidades, incluido el despertar de la conciencia individual ${ }^{39}$ o el descubrimiento de la naturaleza. Ahora bien: como precisa el mismo autor, por entonces el tema de la imitación de Cristo está todavía en sus inicios; «no era todavía el eje normal del comportamiento cristiano». E incluso la praxis de la pobreza voluntaria, paradigma de la imitación de Cristo y sus apóstoles, no siempre tenía esa razón de ser en la sensibilidad religiosa: aquél que elegía la pobreza mendicante para apartarse del mundo no tenía la misma conciencia de su gesto que quien lo hacía para imitar a Cristo. En realidad, el evangelismo no suponía ruptura con la Alta Edad Media, pues ya estaba presente en el monacato clásico; y en suma, las formas de imitación de Cristo podían ser más esquemáticamente teológicas o bien más vivenciales, pero este último modo se abrirá camino con más claridad desde el siglo XIII ${ }^{40}$.

38 J. PAUL, Le christianisme occidental au Moyen Âge, p. 244.

39 J. A. GARCía DE CORTÁZAR, «El Renacimiento del siglo XII en Europa: los comienzos de una renovación de saberes y sensibilidades», Renovación intelectual del Occidente europeo (siglo XII), XXIV Semana de Estudios Medievales, Estella, 14-18 de julio de 1997, Pamplona, 1998, pp. 29-62.

40 Son útiles las profundas reflexiones de J. PAUL, La Iglesia y la cultura en Occidente (siglos IXXII), 2: El despertar evangélico y las mentalidades religiosas, Barcelona, 1988, capíts. IV-VI de la 2. ${ }^{\text {a }}$ parte.

Hispania Sacra, LVIII

118, julio-diciembre 2006, 449-487, ISSN: 0018-215-X 
LAS CAUTELAS NECESARIAS SOBRE LA EVOLUCIÓN DE LA ESPIRITUALIDAD. UNA REFLEXIÓN METODOLÓGICA

Como conclusión a lo expuesto, en primer lugar parece necesario afinar el análisis del significado de algunas manifestaciones piadosas y de las consecuencias de las mutaciones espirituales; en segundo lugar, conviene una mayor prudencia al atribuir los cambios descritos de forma generalizada al periodo de los siglos XI-XIII; y por último, probablemente se debe precisar mejor la cronología de inflexión en las tendencias.

Se ha indicado cómo algunas manifestaciones de la piedad orientada a Jesucristo pueden no significar necesariamente un nuevo reconocimiento de su papel en la vivencia de la fe: A) desde la teología o cultura clerical erudita, la atención a la encarnación puede consistir en considerar un «movimiento divino» inevitable de descenso para elevar a la humanidad, en la lógica de la salvación; B) en los movimientos populares de masas ligados a la peregrinación y las búsquedas milenaristas (cruzadas populares), al menos en ciertos ambientes la esperanza mesiánica en Cristo no implica ineludiblemente su aceptación como modelo e inspiración de la propia acción en el mundo, sino la espera escatológica que integra su segunda venida triunfante en un terrorífico escenario final, lucha contra Satán incluida, para inaugurar un definitivo Reino metahistórico. C) El éxito de los relatos apócrifos de la vida infantil y familiar de Jesús puede encuadrarse en el afán general de retorno a las fuentes, pero parece un exponente del gusto exacerbado por los milagros (común al culto a los santos), más que un estímulo nuevo para el seguimiento de Cristo. Y D) Las corrientes espirituales referidas al «evangelismo» (pobreza voluntaria o vita apostolica) dieron frutos, desde luego, pero aún no generalizados en el siglo XII e interpretables de modo diverso.

A todo lo dicho añádanse las consideraciones que siguen.

En un tiempo de «despertar evangélico», perduran el desprecio del mundo y el ascetismo monástico, y continúa incidiendo fuertemente en las conciencias religiosas el poderío de Dios con un sentido de lo sagrado (ordalías) a menudo propio del paganismo. La centralidad de la figura de Cristo no desplaza los argumentos del Antiguo Testamento ni tampoco a la figura de Dios Padre, omnipotente y juez supremo. Y aunque el modelo de santidad inicia un cambio (prevalencia de la caridad, subordinación de los milagros al modo de vida, fin de la idea de predestinación a ser santo), sigue vigente el culto supersticioso a las reliquias de los santos, si bien las de María y Jesús generan ahora más peregrinaciones.

El «descubrimiento místico» de los siglos XI y XII parece muy restringido. No infravaloramos la mística afectiva de un Guillermo de Saint Thierry (m. 1148) y de San Bernardo (1091-1153) y la escuela cisterciense. Pero lo usual en 
la vida orante es la petición, la alabanza y la especulación, más que el diálogo ${ }^{41}$; y esos místicos meditan sobre el amor de Dios conservado como impronta en la memoria de cada criatura, que puede conocerlo partiendo de su razón y moviendo su voluntad ${ }^{42}$. Parece que se trata de una mística un tanto «natural», que en cierto modo prescinde de la mediación de Cristo y la gracia ganada por Él.

De otro lado, se puede y se debe profundizar en el sentido de algunos fenómenos. Por ejemplo, en relación con la iconografía pasionaria algunos estudios han señalado que no pretende la contemplación de los dolores de Jesús, sino más bien representar la redención simbólicamente, exponer la historia de la salvación ante los ojos de los fieles, como ocurre en la vidriera de las catedrales de Chartres (a comienzos del siglo XIII), Bourges o Rouen ${ }^{43}$.

También parece necesario matizar cronológicamente la aceptada identificación de los siglos XI y XIII como «edad de Cristo». Investigadores autorizados se decantan por fijar en el XIII, y no antes, la línea a partir de la cual empieza a pasar al primer plano teológico la humanidad más que la divinidad del Hijo de Dios, llegando a afirmar que «la humanidad de Jesucristo [había estado] hasta entonces mantenida en un segundo plano y un tanto eclipsada por una permanencia más o menos declarada de un cierto monofisismo» ${ }^{44}$. Este último término no nos parece exagerado. Aunque sin rupturas con esquemas previos de vida interior, sólo por su frecuencia deben valorarse las experiencias místicas de tantas beguinas y santas del siglo XIII, con sus éxtasis nupciales con Cristo y su base neotestamentaria. Y para insistir en el siglo XIII, a menudo la contemplación amorosa y unitiva de los sufrimientos de Jesús tiene influjo franciscano ${ }^{45}$. San Francisco de Asís se identifica con Cristo doloroso en la cruz hasta sufrir sus estigmas ${ }^{46}$ y compone el

41 La prière au Moyen Âge: littérature et civilisation, N. BÉRIOU, J. BERLIOZ et J. LONGÈRE, directeurs, Aix-en-Provence 1981; Prière au Moyen Âge: pratiques et expériences (V-XVe siècles), Turnhout 1991.

42 M. A. Ladero Quesada, Historia Universal. Edad Media, p. 517.

43 A pesar de las sugerencias inequívocas del programa iconográfico de Chartres con sus prefiguraciones del Antiguo Testamento (Jonás, Moisés y la serpiente de bronce, Isaac, el Cordero) y sus escenas explícitas de la Pasión, José Sánchez Herrero distingue atinadamente la mera exposición asertiva del plan redentor de Dios, de un lado, de las manifestaciones devocionales y afectivas hacia la Pasión, crecientes entre los siglos XIII y XVI, de otro.——Piedad y artes plásticas. La devoción a la Preciosa Sangre...», pp. 425-426.

44 J. SÁNCHEZ HERRERo formula esta afirmación y desarrolla la idea en «Desde el cristianismo sabio a la religiosidad popular en la Edad Media». Vid. su exposición sobre «Francisco de Asís (11821226), una ruptura y una nueva espiritualidad cristiana tanto en el plano intelectual y elitista como en el popular», pp. 329 ss. Una buena biografía reciente: J. LE GoFf, San Francisco de Asís, Madrid, 2003 (ed. orig. en italiano: 1998).

$45 \mathrm{Vid}$. las referencias a sus textos originales y a la bibliografía especializada en el capítulo sobre «Les débuts de la mystique» de J. PAUL, Le christianisme occidental au Moyen Âge, pp. 341-344.

46 Todas las referencias que siguen sobre el protagonismo de autores espirituales del siglo XIII en la devoción hacia la sangre de Cristo, en J. SÁnCHEZ HERRERO, «Piedad y artes plásticas...», pp. 421 ss. 
difundido Oficio de la Pasión u Oficio de la Cruz; Santa Clara de Asís comparte esa espiritualidad y medita la oración de las cinco llagas; terciarias franciscanas como Santa Ángela de Foligno (1248-1309) eran devotas de la Sangre de Cristo, igual que Santa Catalina de Siena, conmovida ante la visión de la sangre que al manar de las heridas del Señor salva y vivifica la Iglesia. También en el siglo XIII, uno de los autores más influyentes en la popularización de la piedad hacia la Preciosa Sangre de Cristo, para Sánchez Herrero, fue el franciscano Pedro de Juan Olivi (c. 1247-1298), quien contemplaba el costado abierto del que salían la sangre y el agua generadoras de la eucaristía y el bautismo.

Es cierto que en el siglo XII se empezó a vivir con intensidad la Semana Santa, se inició el injerto en la liturgia de representaciones dialogadas de la Pasión, para Guillermo de Saint-Thierry meditar la Pasión de Cristo equivalía a comulgar $^{47}$, y Jacques Le Goff defiende que en esa centuria comienza el deslizamiento de la imagen histórica de Cristo desde el héroe triunfante al Cristo sufriente ${ }^{48}$. Pero el mismo autor sitúa en el XIII lo que llama la dolorización de la piedad, una tendencia que engloba igualmente el fervor y culto marianos. El siglo XIII marca el paso de la meditación sobre Cristo y la redención (meditación especulativa y filosófica sobre la Pasión como acción salvadora de triunfo, salvo la más afectiva en grupos selectos) a la imitación e identificación con Él. En esta centuria se empieza a generalizar el más diáfano cristocentrismo y se produce la auténtica mutación espiritual ${ }^{49}$. He aquí el marco teórico crítico desde el cual cabe plantear la pregunta sobre el significado real de las expresiones de la fe y devoción aparentemente tan centradas en la figura de Cristo.

Con todo, aún se puede cuestionar si, en el doscientos, hay un descubrimiento generalizado de Jesucristo Hombre tanto como Dios. Nótese que la devoción a la Cruz lo es más a la cruz vacía triunfante y victoriosa (la prueba es la fiesta de la Exaltación de la Santa Cruz, el 3 de mayo, hoy eliminada del calendario litúrgico aunque viva en su folklore) que a la cruz pasional ${ }^{50}$, instrumento del suplicio con el Crucificado clavado en el madero y que invita a compartir sus sentimientos. En el propio siglo XIII ¿se extiende una verdadera revalorización de la encarnación? ¿Hay una radical reorientación de la piedad hacia el eje de Jesucristo encarnado, muerto y resucitado y entregado en la eucaristía, y al que se quiere imitar según la consigna de «seguir desnudo a Cristo desnudo» ${ }^{51}$ ? La

47 J. SÁnChez Herrero, Historia de la Iglesia, II: Edad Media, p. 323.

48 J. LE GofF, ¿Nació Europa en la Edad Media?, p. 72.

49 J. SÁNCHEZ HERRERO, «Piedad y artes plásticas...», p. 411.

50 Entre otros, vid. J. LóPEZ MARTín, «La Semana Santa en la religiosidad popular: Andalucía, Castilla, Murcia. Las hermandades y cofradías en la Semana Santa de España», Memoria Ecclesiae XX (2002), p. 442.

51 Es la máxima por excelencia del despertar evangélico, pero «se manifiesta en la Iglesia y se comunica a determinados laicos».—J. LE GoFf, ¿Nació Europa en la Edad Media?, Barcelona, 2003, p. 72 . 
respuesta condicionará también el análisis de las muestras de devoción pasionista del final de la Edad Media; al menos, ayudará a tener en cuenta la complejidad con que ésta se declina y, en suma, a comprender algo mejor «ese intrincado, enredado, implicado mundo de las devociones $»^{52}$.

Sirvan estas reflexiones para insistir en los fenómenos de continuidad, integración y readaptación de corrientes piadosas, pluralidad en los comportamientos enraizados en modelos teológicos similares..., y también para evitar extrapolar al común de los fieles las novedades devocionales propias de determinados grupos. Cierto que cuando una tendencia religiosa obtiene la adhesión de la mayor parte de los fieles y del clero hay que pensar en la existencia de un substrato social y espiritual no sólo propicio a su acogida, sino incluso nutricio o generador de las nuevas propuestas. Pero para los historiadores es más fácil rastrear la fenomenología de las prácticas y ofrecer imágenes simplificadoras de la prevalencia de una u otra espiritualidad en cada periodo, antes que la compleja tarea de discernir la dinámica de las tendencias espirituales en sus superposiciones e interacción. Tales tendencias se expresan a menudo en «ciclos recurrentes», «sucesivos impulsos» y «diferencias de ritmo» ${ }^{53}$; y las diferencias y variabilidad no son sólo regionales, sino que conectan con los cambios sociales, las mutaciones institucionales de la Iglesia y las relaciones entre Iglesia y poderes seculares.

Finalmente, nunca puede perderse de vista la diversidad de niveles de formación y aspiraciones, existente, como bien se sabe, no sólo entre clero y laicado sino en el seno del último y también entre el clero secular y entre las diferentes opciones regulares. Las lógicas ambivalencias y la complejidad de las corrientes espirituales, con diferente espesor, duración histórica, impulsos a largo, medio y corto plazo y estímulos desde la jerarquía o desde las masas, invitan a la prudencia a la hora de calificar la espiritualidad de una época, por mucho que el historiador deba aspirar a encontrar generalizaciones que la hagan comprensible.

\section{La baja EdAd Media: El CUlto a CRisto y El FERvor hacia la PASióN}

No hay duda de que las transformaciones en las tendencias espirituales que hemos identificado con el cristocentrismo, aún con todos los matices y reservas, se intensificaron en los siglos XIV y XV. Pero es más: probablemente en bas-

52 Sobre la no simplicidad de las devociones: J. SÁNCHEZ Herrero, «Piedad y artes plásticas...», p. 432.

${ }_{53}$ Consideraciones imprescindibles que introduce I. Sanz en relación con la periodización de la Historia de la Iglesia y las reformas. I. SANZ SANCHO, «Para el estudio de la Iglesia medieval castellana», pp. 78-79.

Hispania Sacra, LVIII

118, julio-diciembre 2006, 449-487, ISSN: 0018-215-X 
tantes aspectos fue en estas últimas centurias cuando se iniciaron, en particular al ir ligadas a aquellos nuevos medios de difusión de la fe que incidían en la figura de Jesucristo, como la predicación. Entre los sermones, los más cristocéntricos eran los populares en «misiones» o por Semana Santa — las Siete Palabras-, más que los «universitarios» (de corte doctrinal) o los sustentados en enxenpla y vidas de santos. La generalización e incluso el inicio, pues, de la devoción a la Pasión, habrán de esperar a los últimos siglos medievales. Incluso no sólo no es tan obvia la piedad pasionista, sino también el propio cristocentrismo. Algunos autores ven imprescindible aclarar que la espiritualidad centrada en Cristo, la Encarnación y la Salvación fue el substrato religioso fundamental en los siglos XIV y XV a pesar de que sugieran lo contrario fenómenos como la eclosión de santuarios dedicados a la Virgen y la exhuberancia del culto a tantos santos intercesores; y que, en suma, en ese tiempo la devoción a Cristo dominó sobre las demás ${ }^{54}$.

A partir de ello, hay unanimidad para afirmar que la piedad se decantó hacia los sufrimientos de Jesús en sus episodios y detalles más dramáticos. Conviviendo con los temas gozosos del mensaje cristiano (Navidad, Anunciación), la Pasión se convirtió en el motivo central de la devoción, de las representaciones artísticas y de la liturgia (pero no tanto debido a las crisis o mutaciones bajomedievales ${ }^{55}$ ). Todo ello ha sido puesto de relieve con solidez y amplitud por los historiadores de la religiosidad y de la liturgia, del arte y de la literatura. Entre las manifestaciones de devoción a la Pasión veremos sólo algunos ejemplos que nos parecen relevantes: los significados pasionistas de la misa, la devoción a la Sangre y al entierro, los disciplinantes, las cofradías de la Vera Cruz, la devoción a los instrumentos de la Pasión y sus reliquias, el enriquecimiento de la iconografía pasionista, la costumbre de meditar los sufrimientos de Jesús y el inicio de formas colectivas de hacerlo, y el despliegue de las representaciones y otros elementos de Semana Santa.

A) En estos siglos, partiendo del hecho de que la misa es la renovación del sacrificio de la cruz, se entiende como alegoría de la Pasión, cuyos episodios

54 G. Lobrichon, La religion des laïcs en Occident. XIe-XVe siècles, París, 1994, p. 197.

55 Se ha cuestionado la relación entre las crisis ligadas a la peste negra y el sentido patético de la religiosidad. Vid. E. Mitre FernándeZ, La muerte vencida: imágenes e historia en el Occidente medieval (1200-1348), Madrid, 1988. J. Paul sigue a los cronistas: terminada la peste, «la vie reprend le dessus avec vigueur et même avec une frénésie de jouissance inconnue jusque-là», como atestiguan las fiestas, los gastos suntuarios y las obras de arte (Le christianisme occidental, p. 298). Y si en los siglos XIV y XV el horror de la muerte y lo macabro están presentes, las celebraciones funerarias acusan la mezcla entre tradición y nueva sensibilidad, sentido trágico y frenética alegría de vivir; la muerte «est investie de sentiments complexes, plus équilibrés qu'il n'y paraît», Ibidem, p. 335. Ello no impide el progresivo triunfo de la interiorización espiritual. 
van siendo recordados paso a paso y con extremo detalle en cada objeto de altar, ornamento, color, gestos, palabras o silencios del clérigo ${ }^{56}$. El alegorismo místico-simbólico y dramático como clave de interpretación de los ritos litúrgicos se inició en el siglo IX, ilustres tratadistas lo secundaron ${ }^{57}$ y triunfó en el bajo medievo. En el siglo XIII castellano lo encontramos en la Partida I (tít. 4), en Del sacrificio de la misa de Gonzalo de Berceo; y, entre otros, en el Tractado de lo que significan las cerimonias de la misa y de lo que en cada una se deve pensar y pedir a nuestro Señor [c. 1480] de fray Hernando de Talavera, primer arzobispo de Granada (1493-1507) ${ }^{58}$, aunque esta obra destaca por las exhortaciones morales que el jerónimo introduce aprovechando la sintonía del pueblo con esta línea simbólico-dramática. La misa aparece como puesta en escena teatral de la muerte y la resurrección del Señor. Es algo que puede llegar a unos fieles que no comulgan pero que perciben los gestos y estímulos sensoriales (luces, sonidos de campanillas, incensaciones, música, silencio). Por descontado, se oscurecen los significados genuinos de la liturgia: alabanza, oblación sacrificial de Cristo al Padre realizada por la Iglesia, acción de gracias, banquete fraterno...

No fue absolutamente omnipresente el alegorismo pasionista de la misa. Jean Gerson (1363-1429), el célebre maestro de teología de París e inspirador de una mística personalista, se contentaba con exigir a los fieles que asistían a la misa compostura, recitar o cantar el Confiteor y el Sanctus y pensamientos de contrición, alabanza y fraternidad. Unos mínimos que, al decir de Vincent Tabbagh, no buscaban asociar a los fieles verdaderamente a los misterios sagrados $^{59}$, pero que, además, eludían la explicación alegórica pasionista. En todo caso, la última fue compatible con la noción de la eucaristía como epifanía milagrosa de Dios, intensificada tras el IV Concilio de Letrán y su fijación rotunda de la presencia real de Cristo, noción que generaría desde el siglo XIII

56 Por ejemplo, el silencio cuando empieza el canon significa el comienzo de la agonía dolorosa en la cruz; los brazos extendidos del sacerdote recuerdan al crucificado; las campanillas que se tocan en la Elevación significan las voces de los soldados que fueron a prender a Jesús; las cinco plegarias del canon recuerdan las cinco llagas; las palabras Nobis quoque en voz alta significan la confesión del buen ladrón; la acción del sacerdote tapando el cáliz con la patena recuerda la losa cubriendo el sepulcro de Cristo, etc.

57 Desde la segunda mitad del siglo XI proliferan las explicaciones de la misa en esa línea (como el anónimo Micrologus de ecclesiasticis observationibus, ¿de Bernoldo de Constanza, m. 1100?). Como escolástico alegorista del XIII destaca Guillermo Durando, m. 1296 (Rationale divinorum officiorum).-Una detallada lista de autores y obras en M. RiguetTi, Historia de la liturgia, I, Madrid, 1955 , pp. $55-58$ y $77-81$.

58 En Nueva Biblioteca de Autores Españoles, XVI (Escritores Místicos Españoles, 1). M. MENÉNDEZ Y PELAYo, director, Estudio preliminar de Miguel MIR, Madrid, 1911.

59 Según el tratado atribuido a Gerson Comme on se doit maintenir à la messe.- - V. TABBAGH, «La pratique sacramentelle des fidèles, d'après les documents épiscopaux de la France du Nord (XIII $-\mathrm{XV}^{\mathrm{e}}$ siècles), Revue Mabillon, Nouvelle Série 12, t. 73 (2001) pp. 159-204, el dato en p. 187.

Hispania Sacra, LVIII

118, julio-diciembre 2006, 449-487, ISSN: 0018-215-X 
el rito de la Elevación ${ }^{60}$ desde el fervor por «ver a Dios» y después, desde 1264, la fiesta y procesión del Corpus Christi. Además de esa compatibilidad, el culto a las especies consagradas y la devoción a la Pasión estaban muy ligados. El trasfondo teológico de la línea alegórico-dramática es el de la misa como re-presentación del sacrificio del Calvario. Circulaban relatos de milagros con la Sagrada Hostia o los corporales sangrantes ${ }^{61}$ y es muy elocuente la leyenda de la «Misa de San Gregorio», creada en el siglo XIV: celebrando misa, el papa Gregorio I Magno (590-604) tuvo la visión de Cristo en el altar derramando su sangre que llenaba el cáliz; en la iconografía de este milagro decoran el altar los instrumentos del suplicio: cruz, espinas, clavos, escalera, flagelo.

B) La Crucifixión pasa a ser la representación más importante de la Pasión, en parte porque permite la exhibición de la Preciosa Sangre de Cristo, objeto de gran devoción (iniciada en el siglo XIII, se prodiga en los siguientes dentro y fuera de España; exponentes destacados fueron Catalina de Siena o Juliana de Norwich $)^{62}$, que generó representaciones de las santas llagas manando sangre recogida por ángeles en cálices, las alegorías del Lagar Místico y la Fuente de Vida, las controversias sobre la veracidad de las ampollas con la Sangre del Señor o, en relación con ello, las leyendas sobre el Grial, etc.

C) Con la crucifixión se extendió la iconografía del entierro. «La exhibición, junto con la crucifixión, de la deposición en la tumba abre la puerta a una meditación sobre el cadáver que, a partir del siglo XIV, impregnará la sensibilidad macabra» ${ }^{63}$. Es el diagnóstico de Jacques Le Goff sobre la tendencia a la «dolorización y la devoción de Cristo» iniciada en el siglo XII. Pero la absoluti-

60 Una completa síntesis en M. RuBIN, Corpus Christi. The Eucharist in Late Medieval Culture, Cambridge, 1999. Un resumen del estado de la cuestión sobre el culto medieval al Sacramento en el seno de la misa: R. TORRES JimÉNEZ, «Devoción eucarística en el Campo de Calatrava al final de la Edad Media. Consagración y elevación», Memoria Ecclesiae, XX (2002), Religiosidad popular y archivos de la Iglesia, 293-328. Vid. R. BÉRAUDY, «El culto de la Eucaristía fuera de la misa», La Iglesia en oración. Introducción a la liturgia, A. G. MARTIMORT, director, Barcelona, 1964, pp. 506-507; J. A.

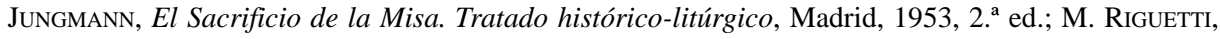
Historia de la liturgia, I.

61 J. BAUCELLS REIG, «Hostia consagrada incorrupta y corporales ensangrentados en el monasterio benedictino de San Cugat del Vallés, obispado de Barcelona», en Memoria Ecclesiae, XX (2002), pp. 265-291; J. P. PAStor ARIÑo, «La vivencia eucarística en Daroca», Ibidem, pp. 205-210. Los relatos sitúan el origen de estos milagros al final del siglo X y en el XIII a causa de la amenaza islámica (ocultación de una hostia consagrada en unos corporales luego ensangrentados). Pero su difusión y la dignificación cultual de los corporales son bajomedievales. Vid. M. RuBIN, Corpus Christi. The Eucharist in Late Medieval Culture.

62 J. SÁNCHEZ HERRERO, «Pasión y sangre...», p. 139.

63 J. LE GoFf, ¿Nació Europa en la Edad Media?, p. 72. 
zación de la «sensibilidad macabra» y de unas formas externas dramáticas para la religiosidad bajomedieval ha sido contestada ${ }^{64}$.

D) Los movimientos y cofradías de disciplinantes, con su despliegue escenográfico, su intención expiatoria y su dudosa ortodoxia, surgidos antes de la Peste Negra ${ }^{65}$, se multiplican después. En España surgen a comienzos del siglo XV por influjo de San Vicente Ferrer, y practican la flagelación las cofradías de la Vera Cruz o de la Sangre en la noche del Jueves al Viernes Santo ${ }^{66}$. Excepcionales en el siglo XV, existen en el XIV en la Corona de Aragón ${ }^{67}$.

E) Una faceta muy importante de la devoción a la Pasión es la adoración a los objetos emblemáticos que la representan, reliquias como los fragmentos de la Verdadera o Vera Cruz, la Santa Espina, la Corona (la Sainte Chapelle de San Luis de Francia fue su relicario más suntuoso), o Sudarios y ampollas con la Sagrada Sangre. Además, se multiplica el uso de la cruz, árbol de la Vida y arma contra el diablo (como indicaban las biblias de los pobres) y de los crucifijos, donde es representado el Hijo de Dios no sereno sino dolorido.

F) Las imágenes de la Pasión se diversifican y adoptan un expresionismo patético que evoca dolor, recogimiento, angustia, soledad o ternura. A la Crucifixión y el sepulcro se suma una amplia gama de personajes y elementos. Así, la Verónica, la Santa Faz en su lienzo, el Cordero, las tres Marías o el Cristo de la Piedad (sentado y solo, en angustiada espera del suplicio), el Ecce Homo o Varón de Dolores, Cristo yacente, Nazareno. Añádanse las situaciones que tienen a la Virgen María y sus dolores como protagonista. No sólo de pie y con San Juan ante la cruz, sino también al borde del desmayo en el Descendimiento del Hijo y recibiéndolo en su regazo (Virgen de la Piedad) a la vez que ofreciéndolo al Padre ${ }^{68}$.

64 Sobre todo si se toman como signo de una supuesta decadencia propia del «otoño» de los siglos XIV y XV: «No hubo otoño, ni crisis, ni baja Edad Media. Todo lo contrario...». J. SÁnCHEZ HERRERO defiende «el cambio creador y renovador en todos los aspectos de la religiosidad de los siglos XIV y XV».-Iglesia de la Historia, Iglesia de la fe. Homenaje a Juan María Laboa Gallego, Madrid, 2005, 41-66, en especial pp. 61 y 65.

65 Además de las florentinas y peruginas del siglo XIII, hay procesiones de disciplinantes en Prato desde 1335.-M. A. LADERO QUESADA, Las fiestas en la cultura medieval, Barcelona, 2004, pp. 119-120.

66 Cfr. J. SÁNCHEZ HerRero, «Pasión y sangre...», pp. 132-135; ID., «Las cofradías de Semana Santa durante la Modernidad. Siglos XV al XVIII», Primer Congreso Nacional de Cofradías de Semana Santa, Zamora, 1988, pp. 27-68; ID., Las diócesis del Reino de León. Siglos XIV y XV, León, 1978, 266-267.

67 Se documenta una así en Játiva desde 1333.—J. SÁNCHEZ Herrero, «Pasión y sangre...», p. 131.

68 Una tipología jerarquizada de las imágenes de la Pasión nos da el siguiente orden de frecuencia: Crucifixión, Flagelación, Coronación de Espinas, Varón de Dolores, Cristo de la Humildad y Paciencia, el Cristo despojado de sus vestiduras esperando ser crucificado, el velo de la Verónica, la Piedad, y el Cristo yacente o Santo Entierro. Finalmente, el Nazareno vestido con su túnica caminando con la cruz a cuestas, pero también abrazado a la cruz. Los tres últimos se prodigan más desde el siglo XVI. J. SÁNCHEZ HERRERO, «Pasión y sangre...», pp. 138-139. Para la tipología de representaciones ha citado a 
G) Una vertiente muy importante de la devoción a los dolores de Jesucristo es la contemplación intimista de la Pasión. En el extremo de esta meditación afectiva y aflictiva de antiguas raíces ${ }^{69}$, ya en la línea de la total y sensorial identificación con Cristo se sitúan los estigmas de algunas místicas del siglo XV. Se procuraba padecer con el Señor y con la Virgen internamente. Se difundieron ejercicios de devoción a los dolores de María como las estaciones de los Siete Dolores - hasta el XIV fueron cinco ${ }^{70}$. Las procesiones de flagelantes manifiestan la misma piedad aunque orientada a la expiación. Los libros de Meditationes, y visiones muy difundidas, invitaban a meditar en los «mil pasos» del Señor con la cruz a cuestas, o en sus «cinco mil quinientas heridas», en las siete caídas, las llagas, las siete palabras... evocando todos los detalles físicos y espirituales. Se dejaba sentir la influencia del franciscanismo, los místicos renanos (Enrique de Suso, m. 1365), Santa Brígida de Suecia (m. 1373) y la Devotio Moderna (Imitación de Cristo de fray Tomás de Kempis, m. 1471). En el siglo XVI se terminó de configurar el Viacrucis como recorrido orante traído de los Santos Lugares e iniciado en el siglo XV. También a fines del XVI se harían comunes los Calvarios.

H) Veamos el contexto litúrgico de la celebración de la Pasión. Era recordada todos los viernes, pero la Semana Santa era el tiempo fuerte del año polarizado en la redención cruenta y gloriosa. Lo esencial era el triduo pascual. Al margen del Jueves de la Cena y el «monumento» eucarístico (que para González Novalín sustituye al «sepulcro» levantado en ciudades centroeuropeas), y de los aludidos sermones de Pasión del Viernes Santo, tiene interés la representación de «misterios» y dramas de Pasión dentro y — las más populares- fuera de los templos ${ }^{71}$. Fue más común escenificar la crucifixión y el entierro de Cristo desde el siglo XVI, y son propios de la Modernidad la liturgia de la exaltación de la santa cruz el domingo de Pascua, los cortejos del domingo de Ramos que incluían adoración de la cruz y penitencia ${ }^{72}$, las muy populares procesiones

J. CAMÓN AZNAR, Los grandes temas del arte cristiano en España, t. III: La pasión de Cristo en el arte español, Madrid, 1949, p. 47.

69 N. PIRosKa, Le don des larmes au Moyen Âge. Un instrument spirituel en quête d'institution (Ve-XIIIe siècles), París, 2000.

70 Tanto los Siete Dolores como la iconografía de las Siete Espadas son contrapunto de los Siete Gozos de María, venerados ya en el siglo XIII. Sobre la iconografía occidental de la Virgen, vid. L. RÉAU, Iconografía del arte cristiano, tomo 1, vol. 2: Iconografía de la Biblia. Nuevo Testamento, Barcelona, 2000, pp. 80-134.

${ }^{71}$ Una buena puesta al día bibliográfica en M. A. LADERO QUESADA al referirse a las celebraciones religiosas, en Las fiestas en la cultura medieval, notas 20 y 23 del capítulo 5, p. 201. Destaquemos K. Young, The drama of the medieval Church, Oxford, 1933; R. E. SuRTZ, Teatro castellano de la Edad Media, Madrid, 1992; A. GómEz MoReno, El teatro medieval castellano en su marco románico, Madrid, 1991.

72 En muchas ciudades ese día hacían una «estación» ad portas ecclesiae; allí el celebrante se postraba adorando la cruz mientras era golpeado simbólicamente con palmas y se cantaba la antífona Percutiam pastorem: «Heriré al pastor y se dispersarán las ovejas». Tales datos para el siglo XVI en J. L. GoNZÁLEZ Novalín, «Religiosidad y reforma del pueblo cristiano», pp. 375-376. 
del encuentro, etc. Pero ya antes los «misterios» dieron lugar a «pasiones» en romance: desde fines del XIV (más populares) y en el XV (más teológicas). Eran «pasiones» dramatizadas fuera de la iglesia durante varios días (cuatro en Arras hacia 1430) ${ }^{73}$. Bajo formas rudimentarias se documentan para el siglo XV en Castilla ${ }^{74}$.

Como se sabe, las representaciones proceden de los tropos (diálogos que amplían pasajes litúrgicos). Eran más frecuentes los del ciclo de Navidad-Epifanía que los del ciclo pascual ${ }^{75}$; y es que los primeros se ajustaban más al sentido lúdico y gozoso de estas expresiones. De hecho, un misterio de Pascua muy característico, la Visitatio Sepulchri, escenifica no los dolores de la Pasión, sino el júbilo de Resurrección en la mañana del domingo pascual, igual que la danza litúrgica de algunas catedrales en el mismo día ${ }^{76}$. Estas expansiones lúdico-festivas suscitaban recelos, como ocurría con los sermones de Pascua de ciertas ciudades alemanas (risus paschalis), que para evocar el alborozo pascual recurrían a los chascarrillos obscenos ${ }^{77}$. Los bailes se asociaban a los convites dentro de los templos y al uso de pernoctar en ellos en las vigilias. En este contexto, los propios sermones nocturnos de Pasión y Resurrección acarreaban «inconvenientes y aparejos de pecar» ${ }^{78}$, y puede recordarse que, terminada la Semana Santa, el lunes y martes de Pascua eran dedicados a «regocijos profanos» (batallas de naranjas en Murcia), ya propios de las fiestas de primavera y el posterior tiempo de bodas iniciado el domingo de Quasimodo ${ }^{79}$. Entre el domingo de Pascua y Pentecostés se abría la espita del regocijo primaveral ligado a la estación del amor. Todo ello muestra la complejidad de la devoción pasionista.

El Concilio de Trento terminaría con algunos añadidos extralitúrgicos de origen privado. Así ocurrió con el canto del bello himno Stabat Mater Doloro$s a$ («...juxta crucem lacrimosa / dunc pendebat filius»), eliminado de la liturgia de la Pasión en $1560^{80}$. Recoge la honda contemplación de los sentimientos de

73 El teatro religioso «en las fronteras de la liturgia», los «misterios» $\mathrm{y}$ «pasiones» y su evolución de lo popular a lo teológico: É. Delaruelle, E.-R- Labande y P. Ourliac, La crisis conciliar. La vida religiosa del pueblo cristiano [1378-1449]: Historia de la Iglesia de los orígenes a nuestros días, XVI, A. Fliche y V. Martin, directores, edición española revisada por F. Martín Hernández, Valencia, 1976, pp. 13-38, en especial p. 22 para la Pasión de Arras.

74 En las iglesias de Palencia y de León. J. SÁnchez Herrero, Las diócesis del Reino de León. Siglos XIV y XV, León, 1978, pp. 288-292.

75 J. FERNÁNDEZ CONDE, «Religiosidad popular y piedad culta», La Iglesia en la España de los siglos VIII-XIV: Historia de la Iglesia en España, II-2. ${ }^{\circ}$, pp. 340-343.

${ }_{76}$ Por los canónigos, en Auxerre. M. A. LADERO QUESADA, Las fiestas en la cultura medieval, p. 118.

77 Un estudio teológico y antropológico en M. C. JACOBELLI, Risus Paschalis, Barcelona, 1991.

78 M. A. LADERO QUESADA, Las fiestas en la cultura medieval, p. 122.

79 M. A. LADERo QueSADA, «Medievo festivo», p. 101.

${ }^{80}$ Benedicto XIII lo reintrodujo en 1727 en la misa de la fiesta de los Siete Dolores de la Virgen (15 de septiembre). Pero al versar sobre la Crucifixión, con el tiempo volvió a usarse en Semana Santa, específicamente en la liturgia del Viernes Santo. Así se hizo hasta la encíclica Motu Proprio de 1906.

Hispania Sacra, LVIII

118, julio-diciembre 2006, 449-487, ISSN: 0018-215-X 
la Madre interiorizados por el fiel que desea que arda en amor su corazón ante la cruz:

«Eia Mater, fons amoris $\quad / . .$. fac tu ardeat cor meum in amando Christum Deum / tu sibi domplaceam».

Pocos himnos hay tan expresivos del suplicio de la crucifixión; de los dolores de la Virgen al pie de la cruz con su alma atravesada por la espada profetizada por Simeón («cuius animam gementem / contristatam et dolentem / per transivit gladius»); del sentido de este sacrificio por los pecados humanos («pro peccatis suae gentis / vidit Jesum in tormentis / et flagellis subditum»); del deseo de condolerse con María ( «fac me tecum pie flere / crucifixo condolere / donec ego vixero. / Juxta crucem tecum stare / et me tibi sociare / in plactu desidero») y de la conciencia de que la cruz abre el camino de la gloria.

Para recoger la idea general sobre el protagonismo de la Pasión y del mismo Cristo en las devociones del final del Medievo, procede acudir a Delaruelle, Labande y Ourliac, pioneros del análisis sociológico de la religiosidad medieval en el contexto de la magna obra Histoire de l'Église aparecida en París desde 1935. No vacilan en afirmar que el siglo XV

«se caracteriza por el patetismo que invade el arte y la literatura, y vuelve preferentemente las almas hacia la meditación de los sufrimientos del Salvador, uniendo esta meditación a la idea del pecado de los hombres. El ciclo de Pascua acentúa su preeminencia sobre el de la Navidad e, incluso, se subraya a veces menos la Resurrección que los más pequeños detalles de la Pasión. Para comprender tales obras [las pasiones] hay que recordar también que el hombre del siglo XV, época de realismo, no se contenta con creer... sino que quiere imaginar y ver» ${ }^{81}$.

UNA MUESTRA DE LA REALIDAD RELIGIOSA TARDOMEDIEVAL EN EL MEDIO RURAL CASTELlANO: INDICIOS DE LA DEVOCIÓN A CRISTO DOLIENTE EN EL CAMPO DE CALATRAVA

\section{Las vías de estudio y el campo de exploración}

El conocimiento del elenco de manifestaciones de la religiosidad medieval en Occidente y en la Península, acuñado largamente por la comunidad de investigadores, constituye un poderoso referente metodológico para acercarse al análisis en detalle de las mismas realidades en terrenos concretos. Este análisis debe continuar para enriquecer las interpretaciones del mundo religioso medie-

81 É. Delaruelle, E.-R- Labande y P. Ourliac, La crisis conciliar. La vida religiosa del pueblo cristiano [1378-1449], Historia de la Iglesia, XVI, A. Fliche y V. MARTIN, directores, p. 19. 
val. El bagaje de conocimientos aludido en el apartado anterior procede de una indagación laboriosa en fuentes de muy variada procedencia; por ello resultan tan valiosas las síntesis, las reflexiones y los estudios comparativos, y, por lo mismo, también es importante la tarea de localización y examen crítico de nuevas fuentes para continuar profundizando en líneas de estudio ya emprendidas. A este respecto, cabría reivindicar la necesidad de un mayor esfuerzo teórico en los historiadores de la Iglesia y la religiosidad, en particular una mayor atención de carácter metodológico-epistemológico a sus fuentes.

Toda aportación de datos, por insignificantes que parezcan, es provechosa en un campo difícil de conocer como es el de la religiosidad medieval en sus significados (la espiritualidad). Un conocimiento más laborioso cuando no se trata de aspectos objeto de regulación o punición, localizables en fuentes normativas como las constituciones sinodales o conciliares. De hecho, en cuanto a la vida cristiana éstas suelen suministrar datos sobre disciplina - liturgia, sacramentos- o instrucción ${ }^{82}$; queda diluida la «religiosidad del pueblo» en sus aspectos no oficiales y más emotivos (salvo los usos mortuorios), con excepciones ${ }^{83}$. Algo similar cabe aplicar a tratados como los confesionales y compendios de sacramentos para párrocos. En general es preciso recurrir a fuentes cronísticas, historias locales, literatura y arte ${ }^{84}$, entre otras, así a como textos pastorales de denuncia de supersticiones ${ }^{85}$.

La aportación que nos ocupa tiene el sentido indicado, una contribución de método y datos limitada, pero de interés porque las fuentes medievales para la vida religiosa de las zonas rurales son muy parcas. Procede de una documentación que deja emerger la materialidad y las vivencias de la vida cristiana cotidiana: inventarios de iglesias parroquiales, noticias de advocaciones a las que se acogen templos y cofradías; referencias aisladas al describir el espacio físico de una iglesia con objeto de repararla... Todo ello es posible gracias al diálogo entre una realidad eclesial articulada en parroquias y una instancia superior que se

${ }^{82}$ Lo evidencia el elenco de informaciones sobre la vida cristiana extraído de los sínodos. Vid. I. SANZ SANCHO, «La religiosidad del clero y del pueblo en los sínodos murcianos del siglo XIV», Carthaginensia, V (1989), 31-99; J. C. MATÍAS Y VICENTE, Los laicos en los sínodos salmantinos, Salamanca, 1990.

83 Precisamente utiliza los sínodos A. GarCíA y GARCíA, «Religiosidad popular y festividades en el Occidente peninsular (siglos XIII-XVI)», Fiestas y liturgia. Actas del Coloquio celebrado en la Casa de Velázquez, 12/14-XII-1985, Madrid, 1988, pp. 35-51.

84 Vid. J. SÁNCHEz HERRERO, «La religiosidad popular en la baja Edad Media andaluza», Homenaje a Alfonso Trujillo, II, Santa Cruz de Tenerife, 1982, pp. 279-331. El autor combina a) fuentes sinodales para estudiar la liturgia, la disciplina y las listas de fiestas, con $b$ ) fuentes cronísticas y literarias y documentación de archivos municipales (gastos) y de instituciones eclesiásticas, para las fiestas populares y las cofradías.

${ }^{85}$ Por ejemplo: Pedro CiRuelo: Reprovación de las supersticiones y hechicerías (1538), edición, introducción y notas de José Luis Herrero Ingelmo, Salamanca, 1993. Ediciones anteriores: A. V. EBersole, Valencia, Albatros, 1978, y J. García Font, Barcelona, Glosa, 1977.

Hispania Sacra, LVIII

118, julio-diciembre 2006, 449-487, ISSN: 0018-215-X 
acerca a ella, la inspecciona y pretende corregir, y deja constancia de esta incidencia. Son los libros de visitas señoriales del final de la Edad Media. Ahora bien: por su carácter, esta inspección no coincide de lleno con la información que buscamos; son visitas o inspecciones reglamentistas e interesadas sobre todo por la dimensión material y externa del culto (además de la salvaguarda de la jurisdicción y privilegios de la propia institución señorial). Es cierto que reflejan determinadas conductas en el terreno bien litúrgico o bien devoto. Pero los visitadores nunca buscarán la exhaustividad; no pretenden registrar sistemáticamente todo el acervo de prácticas religiosas, ni, menos, capturar sus significados espirituales desde una imposible mirada antropológica (esperar esto de las visitas sería un anacronismo y una ingenuidad). Ni desde un afán burocrático que tardaría en imponerse aún después de Trento, pero que, aunque existiera, fácilmente omitiría lo que en la época es la normalidad absoluta, aunque el historiador prefiera verla recogida explícitamente. Dicho de otro modo: se trata de meras pistas sobre las orientaciones de la piedad, punta del iceberg de una realidad que, por habitual, no se hace tan manifiesta en estas fuentes.

Acotemos el territorio y las condiciones de la observación. Ahora nuestro objetivo es rastrear los signos de la devoción a Cristo sufriente al final del periodo medieval en el área de observación concreta que es el Campo de Calatrava histórico. Este espacio $\left(11.470 \mathrm{Km}^{2}\right)$, identificable hoy con parte de la provincia de Ciudad Real, se encuadra entre los Montes de Toledo y Sierra Morena, Extremadura y las llanuras manchegas (la cuenca central del Guadiana) ${ }^{86}$. Tiene coherencia administrativa eclesiástica desde el siglo XIII como arciprestazgo de Calatrava del arzobispado de Toledo, dentro del arcedianato de Calatrava ${ }^{87}$; pero como se sabe, su identidad la define su dependencia señorial de la Orden Militar de Calatrava, nacida en el territorio (1158) y artífice de su defensa y colonización ${ }^{88}$.

86 Esta delimitación viene a ser la del partido del Campo de Calatrava, en denominación del siglo XV.

87 E. RodRíguez-PICAVEA, «Aproximación a la geografía eclesiástica del primitivo arcedianato de Calatrava (siglos XII-XVI)», Hispania Sacra, 43 (1991), 735-773. R. TORRES JIMÉNEZ, «El Libro de Beneficios del arzobispado de Toledo [1501] y la geografía archidiocesana», Memoria Ecclesiae. Geografía Eclesiástica Hispana y Archivos de la Iglesia, XXVIII, 2. ${ }^{a}$ parte (2006), 473-502.

88 El señorío medieval del Campo de Calatrava es bien conocido: 1) Dentro de espacios más amplios: J. GonZÁleZ y GonZÁleZ: Repoblación de Castilla La Nueva, 2 vols., Madrid, 1975-1976. Capíts. de R. IZQuiERdo BEnito, M. a José Lop Otín, F. RuIZ Gómez y R. TORRES JimÉnEZ, en La provincia de Ciudad Real, II: Historia, Ciudad Real, 1996, 2. ${ }^{a}$ ed., y de F. RuIz GómEz y D. IguAl LuIs, en Castilla-La Mancha medieval, R. IzQuIERdo BENITO, coordinador, Ciudad Real, 2002; F. RuIz GómEZ, Los orígenes de las Órdenes Militares y la repoblación de los territorios de La Mancha (1150-1250), Madrid, 2003. 2) Con otros dominios calatravos: E. Solano RuIZ, La Orden de Calatrava en el siglo XV. Los señoríos castellanos de la Orden al fin de la Edad Media, Sevilla, 1978, y E. RodRíGUEZ-PICAVEA MATILLA, La formación del feudalismo en la meseta meridional castellana. Los señoríos de la Orden de Calatrava en los siglos XII-XIII, Madrid, 1994; 3) Rebasando el Medievo: M. CoRCHAdo SorIANO, Estudio histórico-económico-jurídico del Campo de Calatrava, 3 vols., Ciudad Real, 1984, 1983 y 1982. 4) En cuanto a fuentes: Espacios y fueros en Castilla La Mancha (siglos XII-XV). Una perspectiva metodológica, J. Alvarado Planas, coordinador, Madrid, 1995. 
Su función organizadora, ejercida en nombre de los monarcas ${ }^{89}$ y en interés propio, entraba de lleno en el ámbito religioso-eclesiástico. De una parte, por su naturaleza: la milicia era filial del Císter con amplias exenciones apostólicas, tenía en el Campo de Calatrava su Convento matriz, sede del gobierno de toda la orden (función, pensamos, compartida — más que transferida - con la villa de Almagro ${ }^{90}$ ); sus miembros eran profesos con deberes religiosos; y su maestre poseía plena autoridad temporal y espiritual, compartida ésta con el Prior del Convento ${ }^{91}$. Pero de otra parte, y esto es esencial, la orden aplicó de lleno en su señorío el modelo feudalizante de iglesia privada o iglesia propia. Tras los pleitos con el arzobispado de Toledo, fueron delimitados los respectivos ámbitos de acción y derechos en diversas concordias ya en las décadas de $1170 \mathrm{y}$ 1240 (se revisarían en el siglo XV). El resultado fue que, a costa de la mitra toledana y con excepción de prerrogativas eminentemente episcopales, la milicia se convirtió en la autoridad eclesiástica natural en el Campo de Calatrava. No sólo para percibir diezmos (salvo el tercio arzobispal) y otras rentas. Aquella autoridad alcanzó a los templos, los clérigos y, lo que más nos interesa, la vida religiosa de los fieles en aspectos como sus prácticas sacramentales y devocionales y los usos morales seguidos en villas y lugares ${ }^{92}$. La incorporación del maestrazgo de Calatrava a la Corona en 1489 (ratificada en 1523) intensificó su tarea vigilante de la salud espiritual y moral de los vasallos, en curiosa emula-

89 Sobre la relación entre órdenes militares y monarquías hispanas, ambiguas y condicionadas por la dependencia apostólica de las primeras, pero abocadas a su integración en la construcción del poder regio: C. DE AYALA MARTíneZ, Las órdenes militares hispánicas en la Edad Media (siglos XII-XV), Madrid, 2003, 697-769.

90 Según mi hipótesis, desde bien entrado el siglo XIV y no desde mediados del XIII. R. TORRES JIMÉnEZ, «¿Espacio urbano frente a Convento? Los maestres calatravos en Almagro (siglos XIIIXIV)», Ciudad Real 1255: El mundo urbano en la Castilla del siglo XIII. Actas del Congreso, Ciudad Real, 25-28/V/2005, M. GonZÁLEZ JIMÉNEZ, editor, Sevilla, 2006, v. II, 329-341.

91 Sobre la relación con el Císter: J. O'CALLAGHAN, «The Affiliation of the Order of Calatrava with the Order of Citeaux», Analecta Sacri Ordinis Cisterciensis XV (1959), 161-193 (compilado en The Spanish Military Order of Calatrava and its Affiliates, London, 1975); también edita Definiciones de la Orden, como D. Lomax; véase también L. R. Villegas DíAZ, «Calatravensis Militia, Cisterciensis Ordinis», Cistercivm, 216 (1999), 547-562.

92 J. O'CALlaghan, «The Order of Calatrava and the archbishops of Toledo, 1147-1245», en Studies in Medieval Cistercian History presented to Jeremiah F. O'Sullivan, Massachussets, 1971. Un esquema comparativo de los acuerdos entre Toledo y las órdenes de Calatrava, Santiago y San Juan: R. Torres JiméNeZ, «Organización eclesiástica», en La provincia de Ciudad Real, II: Historia, 221-243. El análisis de cómo desde la misma conflictividad entre Orden y arzobispo se llega a distintas situaciones en el Campo de Calatrava y en la zona de Zorita: R. TORRES JimÉNEZ, «Modalidades de jurisdicción eclesiástica en los dominios calatravos castellanos (siglos XII-XIII)», en Alarcos 1195. Actas del Congreso Internacional Conmemorativo del VIII Centenario de la batalla de Alarcos (coords. R. IzQuIERdo y F. RuIz Gómez). Cuenca, 1996, 433-458. Una visión más amplia: R. TORRES JimÉnez, Formas de organización y práctica religiosa en Castilla La Nueva. Siglos XIII-XVI (Tesis doctoral Univ. Complutense, 2002). Madrid, 2005, Parte I, caps. 3-7, sobre todo el último.

Hispania Sacra, LVIII

118, julio-diciembre 2006, 449-487, ISSN: 0018-215-X 
ción de las disposiciones sinodales coetáneas ${ }^{93}$. En este contexto las visitas giradas por la milicia calatrava a las villas y lugares de su señorío, en el último cuarto del siglo $\mathrm{XV}$ y después, suministran datos de gran interés sobre su vida religiosa ${ }^{94}$.

Estos datos han de tomarse como una muestra de la vida cristiana en un espacio rural y semirrural castellano, enmarcada en la institución parroquial (una parroquia en cada localidad), y bajo dependencia señorial. Puntualicemos que lo último no pareció incidir en peculiaridades importantes de las formas de piedad en relación con lo conocido en otras zonas. No se constata tanto una proyección devocional de la Orden sobre el dominio, cuanto el hecho de que -en sentido inverso- el Convento mismo de Calatrava era un foco de atracción piadosa, al modo en que cualquier monasterio podía serlo en su entorno ${ }^{95}$. La peculiaridad más relevante puede ser la ausencia de órdenes mendicantes hasta época tardía, dada la reticencia de las órdenes militares a su implantación, con eventuales consecuencias precisamente sobre una menor familiaridad con la piedad hacia Cristo-Hombre. Pero no parece que los límites del señorío fueran frontera para las corrientes espirituales. De este modo, utilizamos las fuentes generadas por la dependencia calatrava del área descrita como vía metodológica para conocer no un dominio sometido a una orden militar, sino más ampliamente un aspecto de la piedad tardomedieval vivida entre el clero y el pueblo del mundo rural.

\section{Los indicios de la devoción a Cristo en su Pasión en las tierras calatravas}

Cabe preguntarse si la espiritualidad del clero y el pueblo en el Campo de Calatrava reproducía el panorama de la devoción a Cristo doloroso generalizado en el mundo cristiano. Al menos, en las últimas décadas del siglo XV y las primeras del XVI. Sin entrar en reflexiones metodológicas sobre la periodiza-

93 R. TORRES JimÉnEZ, «Pecado, confesión y sociedad bajo dominio calatravo al final del Medievo», Os Reinos Ibéricos na Idade Média. Livro de Homenagem ao Professor Doutor Humberto Carlos Baquero Moreno, 3 v., L. Adao Da Fonseca, L. C. Amaral y M. ${ }^{a}$ F. Ferreira, coordinadores, Porto 2003, III, 1267-1274.

94 Basados en ellas: R. Torres JimÉnEz, Religiosidad popular en el Campo de Calatrava. Cofradías y hospitales al final de la Edad Media, Ciudad Real ,1989; ID., «Liturgia y espiritualidad en las parroquias calatravas (siglos XV-XVI)»; ID., Devoción eucarística en el Campo de Calatrava al final de la Edad Media. Consagración y elevación; ID., «Pecado, confesión y sociedad bajo dominio calatravo al final del Medievo». Y con otras fuentes: Formas de organización y práctica religiosa en Castilla La Nueva. Siglos XIII-XVI.

95 R. TORRES JimÉNEZ, «La influencia devocional de la Orden de Calatrava en la religiosidad de su señorío durante la Baja Edad Media», Revista de las Órdenes Militares, 3 (2005), 37-74. 
ción de la Historia eclesiástica ${ }^{96}$, valga el Concilio de Trento (1545-1563) como término del periodo medieval de la religiosidad.

Es sabido que, en la zona, sus cofradías pasionistas y penitenciales de la Vera Cruz sólo se generalizan desde las décadas de 1550 y $1560^{97}$ (en realidad florecerán en el siglo XVII). En Puertollano, Saceruela, Ballesteros (quizás aquí desde $1535^{98}$ ), Daimiel, Carrión o Almagro (desde $1552^{99}$ ), tales hermandades, centradas en sus procesiones y otros usos del Jueves Santo y del Viernes Santo, observaban a menudo prácticas disciplinantes. Tampoco constan las ermitas de la Vera Cruz o Calvarios o humilladeros hasta el último cuarto del XVI en Miguelturra, Puertollano, Tirteafuera, Carrión, Saceruela, Daimiel, etc. ${ }^{100}$. Y al estudiar las numerosísimas cofradías marianas del Campo de Calatrava entre 1470 y $1540^{101}$ apenas documentamos ninguna de tipo pasionista, ni siquiera en su advocación (como hubieran podido ser Nuestra Señora de la Soledad, de los Dolores, de la Piedad o de las Angustias). La excepción es la cofradía de Santa María de las Cruces de Daimiel vinculada al santuario homónimo. Conocemos la ermita con seguridad desde $1486^{102}$, pero en 1465 se vio revitalizada (si no fundada entonces), quizás por difundirse más el milagro

96 Vid. las sugerentes aportaciones de I. SANZ SANCHO, «Para el estudio de la Iglesia medieval castellana», y J. SÁNCHEZ HERRERO, «Unas reflexiones sobre la historia de la Iglesia de los siglos V al

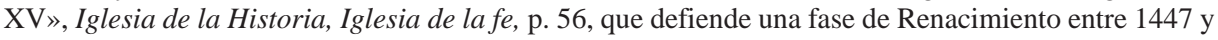
1521.

${ }^{97}$ La Revista Veracruz de Puertollano contiene numerosos artículos sobre las cofradías de la Vera Cruz y es imprescindible consultar los trabajos de González Romero sobre ellas en la Edad Moderna en el Campo de Calatrava: J. R. GonZÁlez Romero, «La Sangre y la Fe: disciplinantes y penitentes en las cofradías manchegas (siglos XVI-XVIII)», Religiosidad popular en España. Actas del Simposium, I, El Escorial, 1998, pp. 607-626; ID., «Orígenes de la Hermandad de la Vera Cruz de Puertollano», Veracruz, 7 (1996); ID., «Documentación cofradiera de los maestrazgos ciudarrealeños en el Archivo Diocesano de Toledo», Las Órdenes Militares en la Península Ibérica, II: Edad Moderna, J. LóPEZ-SALAZAR PÉREZ, coordinador, Cuenca, 2000, pp. 1357-1388.

98 Traslado de pleito anterior: 1579, dic. 30, Sacro Convento de Calatrava. Archivo Histórico Nacional (AHN), Órdenes Militares (OO.MM.), Consejo (Cjo.), Orden de Calatrava (Ctva.), Legajo 6.117 , n 4, f. 48v.

99 Es un ejemplo. Se trata aquí de la fecha no de ordenanzas, sino de los primeros registros de bienes.-Vid. Ch. MAdSEN Visiedo y M. Infante PRIETO: «La documentación de cofradías y hospitales en el Archivo Histórico Provincial de Ciudad Real», Iglesia y religiosidad en España. Historia y Archivos. Actas de las V Jornadas de Castilla-La Mancha sobre investigación en Archivos, Guadalajara, 2002, III, pp. 1359-1372.

100 C. VIÑAS y R. PAZ, editores, Relaciones histórico-geográfico-estadísticas de los pueblos de España hechas por iniciativa de Felipe II: Ciudad Real, Madrid, CSIC, 1971.

101 R.TORRES JimÉNEZ, Religiosidad popular en el Campo de Calatrava. Cofradías y hospitales al final de la Edad Media; ID., «Cofradías bajo advocaciones marianas en el Campo de Calatrava a partir de Libros de Visitas (1491-1510)», Devoción mariana y sociedad medieval. Actas del Simposio, Ciudad Real, 1990, 109-133.

102 Referencia en 1491, abril 11, Daimiel. AHN, OO.MM., Cjo., Ctva., Leg. 6.075, n. 8, f. $172 \mathrm{r}$.

Hispania Sacra, LVIII

118, julio-diciembre 2006, 449-487, ISSN: 0018-215-X 
de la aparición de la Virgen de las Cruces. Para algunos, probablemente se erigió en el siglo XIV ${ }^{103}$.

¿Puede deducirse, de lo tardío de sus hermandades de Pasión, que en el Campo de Calatrava faltó al final del Medievo esta faceta dramática y soteriológica de la piedad cristocéntrica tan común en la cristiandad occidental? Pensamos que no. Lo que se constata es la ausencia de formas organizadas de devoción colectiva a la Pasión hasta mediados del siglo XVI. Ocurre lo mismo que en tantos otros lugares de Occidente: aparte del cauce litúrgico, hasta el XVII predominó el individualismo en la devoción a Cristo doloroso. Será después cuando triunfen las formas de acompañamiento masivo a Cristo en el Calvario $^{104}$.

Por lo tanto, hemos de contar con la escasez y dispersión de los indicios de la piedad pasionista en esta zona a tenor de lo anterior y por otros motivos: carecemos de fuentes como inventarios de libros de devoción de laicos cultos, testimonios artísticos relevantes, ni relatos sobre afamados centros de culto con reliquias, etc., todo lo cual sería más propio de ámbitos urbanos, o con implantación de órdenes monásticas, que del nuestro. Es sabido que las expresiones religiosas, a menudo tan ligadas a lo cívico, son más conocidas en las ciudades; y no sólo por la presencia en ellas de sedes episcopales con su generación documental, sino también por la existencia, en los últimos decenios, de una rica producción historiográfica sobre el mundo urbano medieval que también estudia las manifestaciones de fe colectiva y la fiesta religiosa dentro del enfoque sociocultural y antropológico de la fiesta en general ${ }^{105}$. Por lo tanto, habrá que considerar preciosos, y reveladores de un mundo de piedad más denso y amplio, algunos datos derivados de las advocaciones de templos y cofradías, menciones de objetos litúrgicos de las iglesias, testamentos, etc. Dejamos de lado la piedad eucarística, muy intensa en las tierras calatravas ${ }^{106}$, cuyo sentido es complejo, pues quizás la eucaristía es más venerada como presencia de Dios (aunque salvífica) que vinculada a la Pasión de Cristo.

103 Las Relaciones de Daimiel transcriben un relato del milagro escrito en 1560; la versificación dificulta identificar la fecha de erección de la ermita. W. A. CHRISTIAN lee 1465 (Religiosidad local en la España de Felipe II, Madrid, 1991, p. 103). I. HeRVÁs y BuENDíA también, pero data la imagen en el siglo XIV (Diccionario histórico-geográfico de la provincia de Ciudad Real. Ciudad Real, 1890). Adscribe la ermita al siglo XIV A. J. Moreno, Milagros y exvotos de un pueblo manchego, Ciudad Real, 1989, pp. 169-170.

104 É. Delaruelle, E.-R- Labande y P. OuRliac, La crisis conciliar. La vida religiosa del pueblo cristiano [1378-1449], Historia de la Iglesia, XVI, A. FLICHE y V. MARTÍN, directores, p. 178.

105 Vid. el completo estudio, con valiosas reflexiones sobre la metodología del estudio de la fiesta y abundante bibliografía, de M. A. LADERO QuESADA, Las fiestas en la cultura medieval, Barcelona 2004; ID., «Medievo festivo», en Tópicos y realidades de la Edad Media, III, E. BENITO RUANO, coordinador, Madrid, 2004, pp. 69-119.

106 R. Torres JimÉnEZ, «Devoción eucarística en el Campo de Calatrava al final de la Edad Media». 
No es lo más importante, aquí, destacar la celebración de la Semana Santa, ya que de por sí y oficialmente era uno de los tiempos litúrgicos más relevantes. Los escasos datos al respecto indican la importancia del periodo previo cuaresmal (el espíritu de penitencia se materializa en el uso de tapar con paños blancos — sólo alguna vez, negros - altares, imágenes y sagrarios); recogen la costumbre de levantar el «monumento» el Jueves de la Cena con estrados, cortinajes y verjas; y el Viernes Santo, el de usar velos negros en el templo y celebrar el Oficio de Tinieblas — acompañado de las «matracas». Interesa precisar que las gentes hacían donaciones piadosas relacionadas con estas fiestas, como las «quatro varas de panno negro para la semana Santa» (1495), que mandó una mujer a su parroquia de Daimiel. Por otro lado, era el tiempo de la confesión y comunión prescritas en el Lateranense IV.

La devoción a la cruz y su papel salvador (seguramente dándole el sentido habitual de protección contra el demonio) queda atestiguada en los pueblos del Campo de Calatrava. No en las advocaciones, como se dijo: los Calvarios y las ermitas de la Vera Cruz son tardíos. Sólo cabe mencionar, además de la citada ermita de Santa María de las Cruces daimieleña - con la cofradía que la atiende-, la iglesia parroquial de Saceruela (en terminología de las fuentes, iglesia mayor), titulada Santa María de las Cruces, erigida en 1459 por licencia de la Orden de Calatrava ${ }^{107}$. En general es irrelevante la proporción de las parroquias, ermitas y hermandades dedicadas al Señor en comparación con las marianas y de santos, pero conocemos algunas bajo la advocación del Salvador, que, en línea con el culto a la Pasión, en todas partes fue el título cristológico que triunfó en el siglo $\mathrm{XV}^{108}$ sobre otros como Rey de Reyes, por ejemplo. Bajo este patronazgo contabilizamos dos iglesias mayores o parroquiales, en Calzada y Picón; parecen antiguas pero son muy escasas sobre 59 advocaciones de parroquias. Hay 3 ermitas de San Salvador, las de Calzada, Picón y Almagro (entre 160 aproximadamente) y 2 cofradías, en Almagro y en Calzada (también entre casi 160). Por tanto, a) Sólo dos parroquias tuvieron el título, y además, los templos terminaron perdiendo esa función. Probablemente la iglesia de Calzada, documentada en $1238^{109}$, se llamaba ya San Salvador; pero en la década de 1480 es ermita (la parroquial ha pasado a ser Santa María) ${ }^{110}$. En Picón, San Salvador era la parroquia en el siglo XV y lo siguió siendo hasta que entre 1538 y 1549 se construyó el templo de San Sebastián, más amplio ${ }^{111}$; la anterior per-

107 La referencia a esta fecha en un pleito de 1658 recogido en: 1819, agosto 17, Madrid. AHN, OO.MM., Cjo., Ctva., Leg. 6.172, s.n., ff. 124 y 162.

108 G. LlOMPART, «Longitudo Christi Salvatoris. Una aportación al conocimiento de la piedad popular catalana medieval», Analecta Sacra Tarraconensia (1967), 93-115.

109 Referencia en la Concordia de 1245 entre la Orden y el arzobispo de Toledo.—J. ORTEGA Y CoTES, Bullarium Ordinis Militiae de Calatrava, Madrid, 1761 (ed. facsímil: Barcelona, 1981), p. 80.

110 Referencia a su existencia en 1486: 1491, febrero 21, Calzada. Ibid., Leg. 6.075, n. 8, f. 160v.

111 Las noticias en 1550, abril 30, Corral de Caracuel. Ibid., Leg. 6.080, n. 17, f. 1. 
vivió como centro de culto, pero sólo ermita. b) Entre las tres ermitas de San Salvador contamos las dos anteriores; la tercera está en Almagro (la conocemos desde $1401^{112}$ ). c) Y sólo hay dos cofradías de San Salvador: ejercen sus cultos en la ermitas de Almagro (1493 $\left.{ }^{113}\right)$, y de Calzada (1510 114 ); la primera atiende también un hospital.

La devoción a Jesucristo en su Pasión y, en especial, a la Cruz, encontraba muchos otros cauces. Por lo pronto se entendía que signarse era un elemento esencial de la instrucción cristiana. Cuando en El Moral los oficiales concejiles pidieron a los visitadores licencia para nombrar un «maestro de doctrina», escandalizados por la ignorancia de las criaturas, se fijó que, reunidos niños y mayores en cierta ermita, aprendieran a «sygnarse e la oraçion del Pater Noster e Ave Maria e Credo e la Salve Regina e los mandamientos de Dios». Hacer las tres cruces en frente, labios y pecho, rogando a Dios ser librado de los enemigos, era «cosa tan neçesaria a la salvaçion de las animas averse de saber» ${ }^{115}$.

De otro lado, si bien no documentamos noticias sobre hallazgos o invenciones de cruces (relatos de descubrimientos milagrosos de cruces enterradas), al menos en tres villas del Campo se hicieron votos para guardar la fiesta de la Invención de la Santa Cruz ( 3 de mayo), «la Santa Cruz de Mayo», aunque sin vigilia. Se trata de Argamasilla, Santa Cruz de Mudela - «por razon de los temporales»- y Cabezarados, aquí tardíamente (se votó la fiesta en 1571 a causa del pedrisco); el concejo de Santa Cruz de Mudela daba una caridad al pueblo, especialmente a los pobres ${ }^{116}$. El dato de los votos es importante porque la celebración no era oficial en la archidiócesis de Toledo en que se inscribía la zona: el Sínodo de Alcalá de 1336 la fijó como fiesta, pero fue suprimida por el Libro Sinodal de 1356. Este omitió también la fiesta de la Exaltación de la Santa Cruz (14 de septiembre). Sólo dejaba el Triunfo de la $\mathrm{Cruz}^{117}$ (16 de julio), festividad significativa para la archidiócesis toledana porque se instituyó en memoria del triunfo cristiano contra los almohades en Las Navas de Tolosa (1212), donde participó con sus tropas el propio arzobispo Rodrigo Jiménez de Rada, y la victoria permitió al arzobispado dilatarse hasta Sierra Morena. Volviendo a la Cruz de Mayo, es cierto que los votos citados expresan devoción por el símbolo más característico del cristianismo; pero sin duda incorporan también la costumbre rural medieval de realizar ritos religiosos (rogativas, procesiones a ermitas), precisamente entre el final de abril y los primeros días de mayo para salvaguar-

112 AHN, OO.MM., Calatrava, Sección Diplomática, Carp. 466, n. 283.

113 Ref. en 1495, mayo 8, Almagro. AHN, OO.MM., Cjo., Ctva., Leg. 6.109, n. 35, f. 57r.

114 1510, marzo. Ibid., Leg. 6.076, n. 13, f. 228r.

115 1537, septiembre 25, El Moral. Ibid., Leg. 6.079, n. 9, ff. 254r-v.

116 C. VIÑAS Y R. PAZ, editores, Relaciones... Se trata de las respuestas a la pregunta 52.

117 Publ. J. SÁnCheZ HerRero, Concilios provinciales y sínodos toledanos de los siglos XIV y XV. La religiosidad del clero y pueblo, Sevilla, Universidad de La Laguna, 1976, Apéndice, pp. 229-230. 
dar los campos de plagas, aguaceros, pedriscos o sequías. La fiesta y época acoge otras costumbres como la aún vigente de adornar calles y plazas con cruces floreadas, o los cantares populares antiguos, los «mayos» dedicados a la Cruz, la Virgen, las mozas o Jesús Nazareno. Sin duda, la fiesta encajaba plenamente en el ciclo festivo de primavera-verano con su fuerte sentido folklórico naturalista prácticamente universal y precristiano, exaltado como tiempo del amor y de fecundidad vegetal-animal ${ }^{118}$.

En la línea de rastrear la piedad a la Cruz en función de la aceptación de las fiestas que la veneraban, consta un testimonio de la espiritualidad de la orden de Calatrava. El mismo maestre don Pedro Girón (1445-1466) se mostró muy devoto de la Santa Cruz en su testamento: entre las celebraciones pro anima que encargó al Convento de Calatrava, donde se enterró en suntuoso sepulcro de alabastro $^{119}$, figuraba una vigilia con letanía que el Prior del Convento y los freiles oficiarían anualmente el día de la Exaltación de la Santa Cruz ${ }^{120}$.

En cuanto a las reliquias de la cruz u otras ligadas a la Pasión, los datos proceden de la segunda mitad del siglo XVI, pero en algún caso cabe sospechar una existencia bastante anterior. Las Relaciones de Felipe II mencionan en 1575 la existente en Tirteafuera, lugar de Almodóvar (además, junto a la aldea hay un Calvario): «... una reliquia que se dice ser el Lignum Crucis», sin aclarar desde cuándo la tenían ${ }^{121}$. Se guardaría en la iglesia parroquial de Santa Catalina y fácilmente habría peregrinaciones para venerarla, no documentadas. Por la misma época el Sacro Convento de Calatrava guardaba entre sus reliquias unos trozos de la mesa de la Última Cena y de la Columna donde Cristo fue atado para su flagelación ${ }^{122}$. Cabe suponer fundadamente que el culto tributado a estas reliquias alcanzaría al pueblo, pues el Convento ejercía una indudable proyección devota sobre los fieles del señorío. La milicia fomentó la afluencia de visitas a la casa conventual, y constan durante todo el siglo XV; se obtenía indulgencias por asistir a ciertas celebraciones, y en 1501 Alejandro VI concedió al Prior la prerrogativa pontifical de bendecir solemnemente al pueblo después de misa, vísperas o maitines, lo que redundaría en un atractivo esplendor cere-

118 Javier Fernández Conde recuerda este significado en clave antropológica y otras fiestas litúrgicas medievales de abril a junio (por ejemplo, las Letanías mayores del 25 de abril, San Marcos; o San Gregorio Nacianceno, el 9 de mayo), ligadas a la regeneración del agua y a las rogativas y bendiciones del campo. Las creencias mágico-supersticiosas mezcladas con lo cristiano culminaban en la fiesta solsticial de San Juan Bautista y el ciclo lo cerraba San Pedro el 29 de junio. J. Fernández Conde, «Religiosidad popular y piedad culta», La Iglesia en la España de los siglos VIII-XIV: Historia de la Iglesia en España, II-2. ${ }^{\circ}$, pp. 326-327.

119 E. Solano, La Orden de Calatrava en el siglo XV. Los señoríos castellanos..., p. 104, n. 286.

120 Frey Francisco DE RADES y ANDRADA: Chronica de las tres Ordenes y Cavallerias de Santiago, Calatrava y Alcantara [Toledo, 1572]. Ed. facsímil. Estudio por D. W. Lomax. Barcelona, 1980, f. 77v.

121 1575, diciembre 5, Tirteafuera, Resp. 51.-C. VIÑas y R. PAZ, editores, Relaciones, p. 509.

122 Frey F. DE RAdes y ANDRADA, Chronica de las tres Ordenes y Cavallerias, fol. 9v. 
monial. Más aún acudirían las gentes a venerar aquellos preciosos recuerdos de la Pasión. Además, a los fieles sepultados en el Cementerio de Santa María de los Mártires sito en el Convento, León X les aseguró unas significativas indulgencias hacia 1519: les aplicaba las mismas de los camposantos de Roma y Jerusalén; y ello, porque con autorización papal el comendador de Villarrubia Diego Cabrera trajo para el Cementerio del Convento tierra del primero y también del Campo comprado en Jerusalén con las treinta monedas por las que Judas vendió a Cristo ${ }^{123}$. Sin duda, las reliquias de la Pasión añadían prestigio al Convento como foco religioso ${ }^{124}$.

En las iglesias parroquiales y en las ermitas era continuo y múltiple el uso de cruces, litúrgico u ornamental. Dejamos aparte las «cruces de Calatrava», emblema de la orden, tan abundantes en frontales, paños de difuntos - cruz de Calatrava blanca en paño negro-, alfombras, cortinajes, cálices incluso, vestiduras litúrgicas, etc. Las cruces sin más también eran representadas en esos lugares. Y se pintaban en los frecuentes «cielos» colocados sobre los altares mayores (cortinajes a modo de cubierta celeste), como el «panno colorado questa por çielo ençima del altar con una crus verde», en Santa María de Calzada ${ }^{125}$. También pintaban cruces en el «velum templi», el paño que tantos templos ponían en sus altares; en 1495 una mujer noble o hidalga de El Moral donaba uno de ese tipo a su parroquia de San Andrés — morado, con cruz verde-: «un velum templi de lienço cardeno con una crus verde».

Respondiendo a la nueva costumbre común desde fines del siglo XIV, en los templos calatravos se impuso el poner pequeñas cruces encima del altar para decir misa. Y prácticamente todas las iglesias parroquiales disponían de la «cruz mayor», grande, una de las piezas más valiosas de unos templos en general modestos (de hecho se solían guardar en el sagrario, como los demás objetos $\mathrm{y}$ tejidos preciosos). Las cruces mayores eran ricas, de plata incluso maciza, esmaltadas, labradas o «cercadas de cresteria», armadas sobre madera; tan costosas, que los visitadores intentaban a toda costa que su uso se reservara a los oficios más solemnes. Las hay también de plata sobredorada o con un crucifijo dorado. Se vestían con sus mangas, adecuadas en cada ocasión, que los templos tenían en gran variedad: no faltaban las de simple lienzo y alguna negra, pero en general eran prendas de tejidos finos y ricamente labrados. Muchos donantes pudientes gustaron de mandar mangas de cruz.

En efecto, las mandas piadosas relacionadas con la cruz constituyen un testimonio más, inequívoco, de la predilección de las gentes por este símbolo. He-

${ }^{123}$ Frey F. DE RADES y ANDRADA, Chronica de las tres Ordenes y Cavallerias, fol. 10r.

124 Cfr. R. Torres JimÉnEZ, «La influencia devocional de la Orden de Calatrava en la religiosidad de su señorío durante la Baja Edad Media».

125 1491. AHN, OO.MM., Cjo., Ctva., Leg. 6.075, n. 5, f. 84r. Y 1502: Ibid, n. 31, f. 329v. 
mos aludido a ciertos paños donados que adornaban el altar y llevaban pintada la cruz. Citemos otros ejemplos: Juan Hidalgo y su mujer donaron un pie de madera blanco para la cruz mayor de la iglesia de San Juan de Cabezarados; en 1502, la parroquia de Santa María en Calzada poseía tres mangas de cruz regaladas por dos «dueñas» y por «el alcaide y su dueña», y dos eran ricas y vistosas, de holanda y terciopelo, con bordados en seda, cordones y flecos de colores. En el mismo año «la muger de Anton Martinez Tierno» había donado a Santa María La Mayor en Puertollano un almaizar — velo fino- de seda blanco y rojo para la cruz grande de plata; y otro almaizar de seda cárdeno lo donó al mismo templo «la de Fernán Sánchez la Morena». El comendador de El Viso y Santa Cruz de Mudela, don Fernando de Córdoba, dio a la iglesia de Santa María de El Viso otra manga de la cruz, en terciopelo morado y verde (1502), etc.

Hay que añadir las «crucetas» que coronaban las custodias, y muchas otras como la empleada en Manzanares para el rito de la paz antes de su robo sacrílego: «una cruz chiquita para dar la pas» que era de plata y «se furtó» ${ }^{126}$. La representación labrada de las cruces era, en esencia, el crucifijo (ignoramos sus formas), pero podían llevar otras imágenes al reverso.

No tenemos datos expresos sobre grandes cruces con la imagen tallada del crucificado; quizás serían así las cruces citadas a veces coronando los retablos principales. Ha de tenerse en cuenta, en lo tocante a la devoción popular a las imágenes, que el auténtico éxito lo tenían aquellas tallas que se podían vestir y enjoyar - en particular las de la Virgen-.

Pero contamos con un interesante testimonio en esta línea. Afecta a la iglesia de un pequeño lugar, Picón. Su templo de San Salvador disponía de «una cruz en que besan las mugeres ${ }^{127}$. ¿Se trata de la expresión de una devoción específicamente femenina? ${ }^{128}$. El contexto de este gesto devoto, ¿era el de alguna celebración litúrgica, por ejemplo el Viernes Santo con la adoración de la Cruz, o alguna otra festividad en honor de la Cruz? ¿O bien era una cruz dis-

126 1495, mayo 24, Manzanares. Ibid., Leg. 6.109, n. 37, f. 131r.

127 1538, noviembre 13, Picón. Ibid., Leg. 6.079, n. 19, f. 103v.

128 Sobre las imágenes religiosas y las mujeres, D. RIGAUX, «Dire la foi avec les images, une affaire de femmes?», La Réligion de ma mère. Les femmes et la transmission de la foi, París, 1992, pp. 7190. Para el caso hispano medieval y entrando en el siglo XVI, es obligado consultar las obras de Ángela Muñoz, sobre todo para el misticismo en contexto monástico o independiente de él (beatas, hospitaleras, santeras, beguinas, terciarias...: en suma, las «mulieres religiosae»). Vid. A. MuÑOZ FERNÁNDEZ, «Mujeres y religión en las sociedades ibéricas: voces y espacios, ecos y confines (siglos XIIIXVI)», De la Prehistoria a la Edad Media: Historia de las mujeres en España y América Latina, vol. I, I. Morant, directora; M. Á. Querol, C. Martínez, R. PAstor y A. LaVrín, coordinadoras, Madrid, 2005, pp. 713-743, con una extensa y actualizada bibliografía sobre la religiosidad femenina. Y también: A. Muñoz FernándeZ, Santas y Beatas neocastellanas. Ambivalencias de la religión y políticas correctoras del poder (ss. XIV-XVI), Madrid, 1994; A. MuÑOZ FERNÁNDEZ y M. ${ }^{a}$ M. GRAÑA, editoras, Religiosidad femenina: Expectativas y realidades (ss. VII-XVIII), Madrid, 1991. 
puesta para que espontánea e individualmente la besaran las mujeres? Desconocemos también si tenía un crucifijo al que quizás besaban los pies. En todo caso, parece algo revelador de una piedad emotiva, afectiva, que requiere del contacto sensorial con lo venerado, y que enlaza con el tema de la compasión con Cristo $^{129}$.

La asociación entre la muerte y la salvación por la Pasión queda bien atestiguada, tanto por el protagonismo de las cruces en los oficios de difuntos como por las encomendaciones del alma. En las exequias se colocaba la cruz mayor con su pie - es de suponer que con su manga negra puesta-, junto al féretro cubierto de paño negro y hachas de luz, en medio de la iglesia. Pero a veces los testadores exigían que también durante los responsos encargados para aniversarios y otros días se pusiera la cruz mayor sobre la tumba; esto último fue prohibido por los visitadores, a no ser que se pagara una cantidad añadida por el hecho de «sacar la cruz». En cuanto a las encomendaciones del alma de los testamentos del siglo XV, evidencian cómo se tiene en cuenta el papel absolutamente determinante de la Redención de Jesucristo por su Pasión en la propia salvación. Ello no obsta para que los testadores busquen eficaces intercesores - la Virgen, ante todo-, pero parece clara la noción de la diferencia entre Cristo Dios y los santos. Con todo, esta información de los testamentos es enormemente estereotipada: sus fórmulas han de entenderse como representativas de una mentalidad general, sí, pero oficialista, más que reveladoras de la piedad individual.

Contamos con algunas noticias sobre imágenes con escenas y motivos de la Pasión en las iglesias; probablemente serían mucho más numerosas. Los soportes eran muy variados. Había crucifijos tallados en muchas de las cruces, sin duda; las grandes cruces de plata podían añadir a la espalda otra imagen, como la de Dios Padre, asociado al Sacrificio del Hijo (en la cruz de la iglesia de San Juan en Pozuelo), expresión elocuente del sentido teológico de la Pasión, aunque no sabemos si quedaba minimizada y disminuida de tamaño la figura del

129 Es significativo el conmovedor relato de Pedro el Venerable, abad de Cluny (1122-1156), sobre la muerte de su madre, quien, tras recibir la unción, pidió una cruz; besaba el crucifijo, le lamía los pies, le rogaba con lágrimas: «... Elle porte à ses lèvres l'image de son Seigneur, de sa langue elle lui lèche les pieds, et elle l'étreint sur son visage de toute la force de son corps. Elle adore la Passion du Sauveur, et par sa mort et ses blessures, elle l'adjure de lui donner le salut. Devant tous les assistants, elle confesse que... nulle espérance de salut ne subsiste en elle, hors de la croix de son Seigneur». Quisieron retirarle la cruz y protestó: «... Pourquoi voulez-vous m’enlever mon Seigneur? Laissez-moi donc, aussi longtemps que je vis, celui vers qui je vais m'en aller en mourant» y él explicaba «Ce n'est pas l'image du Christ, c'est le Christ lui-même qu'elle croyait voir sur cette croix, et ne pouvait se résoudre 'a desserrer son étreinte». En descargo del abad y su aceptación de esa identidad entre objeto y realidad representada, recuérdese que el texto se inserta en una reflexión sobre el valor del signum (la cruz) como expresión sacramental de la eucaristía, donde es incuestionable la presencia real de Cristo.-El texto en É. Palazzo, Liturgie et société au Moyen Âge, Mayenne, 2000, p. 174. 
Padre como sucedía en otra partes, en línea con la «especie de reducción del misterio de la Trinidad a una sola Persona ${ }^{130}$. Con este sentido profundo y más simbólico, había representaciones del Cordero (Cristo, Cordero pascual sin mancha, víctima propiciatoria por los pecados del mundo ${ }^{131}$ ): la iglesia de Valenzuela tenía un crucifijo cuyo reverso llevaba el Agnus Dei; y el mismo motivo, en plata, lo había en la iglesia de Luciana; y en la iglesia de El Viso la imagen de la Virgen y el Niño llevaban como adorno «un Agnus Dey con una redezica sobredorada e una sartica azul» ${ }^{132}$. Por lo demás, la parroquia de San Bartolomé de Almagro tenía en 1491 «una tabla con Ecce Homo»; fue un devoto llamado Juan de Pisa ${ }^{133}$ quien donó esta representación tan propia del siglo $\mathrm{XV}$, imagen patética del Varón de Dolores profetizado por Isaísas, rey burlado y flagelado presentado por Pilato. Los frontales de los altares, de guadamecí y tejidos ricos o de simple lienzo, eran lugares propicios para la iconografía; en 1502 la iglesia de Malagón tenía uno con la Crucifixión o parte de la escena y la participación de María, pues tenía «la ymagen de Nuestra Sennora y San Juan» ${ }^{134}$. También centrada en los dolores de la Virgen, en estas tierras era conocida la representación de la Quinta Angustia, por ejemplo, pintada en cierta caja de madera en la iglesia de El Viso (1502). La devoción a la Virgen de las Angustias se difundió mucho en España, pero no sólo aquí. Era la Virgen transida de sufrimiento, cuyo corazón puede verse atravesado por una o siete espadas de dolor; las últimas son los siete dolores o siete angustias (cinco dolores antes del siglo XV); precisamente el quinto es la Crucifixión ${ }^{135}$.

También hay devoción a las Llagas, transcritas como «las çinco plagas» o «las plagas», cuya forma iconográfica ignoramos; en 1495, en la iglesia de San Bartolomé en Valenzuela están en un «estadal de madera», quizás como enorme hacha de luz o bien cortes horizontales o un corazón atravesado por la lanza y rodeado de heridas. Esta piedad a las heridas del Señor en la Cruz, las de pies, manos y costado, tan ligada a la Crucifixión, tuvo un gran auge en particular en el siglo XV a causa de las indulgencias que los papas atribuyeron a las plegarias que veneraban las llagas (sobre todo, protegían contra una muerte sin confesión) ${ }^{136}$. Y no falta el popular tema de la Verónica (el rostro de Jesús coronado

130 Según É. Delaruelle, E.-R- LABANDE y P. OuRliac, La crisis conciliar. La vida religiosa del pueblo cristiano [1378-1449]: Historia de la Iglesia, XVI, FLICHE y V. MARTIN, directores, p. 174.

131 Juan 1, 29; Isaías 53, 1ss.; Levítico 14, 1 ss.; Éxodo 12, 1; Ap. 5,6.

132 1537, igl. Nra. Sra. del Valle. AHN, OO.MM., Cjo., Leg. 6.079, n. 6, f. 12r.

133 Ibid., Leg. 6.075, n.. 7, f. 122v.

134 Ibid., Leg. 6.075, n. 29, f. 186v.

135 Los cinco dolores o angustias: 1) Profecía de Simeón; 2) Huida a Egipto; 3) Pérdida del Niño Jesús en el Templo; 4) Cruz a cuestas; 5) Crucifixión. Y los dos añadidos: 6) Descendimiento de la cruz; 7) Entierro.-L. RÉAU, Iconografía del arte cristiano, tomo 1, v. 2: Iconografía de la Biblia. Nuevo Testamento, pp. 116-117.

136 Ibidem, pp. 530-531.

Hispania Sacra, LVIII

118, julio-diciembre 2006, 449-487, ISSN: 0018-215-X 
de espinas plasmado en el lienzo que le ofreció esta piadosa mujer para secarse camino al Calvario), aunque no siempre su soporte es el más adecuado: un lienzo con su Verónica pintada lo tienen puesto en el sagrario en la iglesia de San Jorge de Aldea del Rey ${ }^{137}$.

\section{ConCLusión}

Los fieles cristianos del Campo de Calatrava encontraban sus cauces para expresar la devoción a la Pasión de Jesucristo. Lo documentamos de modo suficiente pero muy por debajo, sin duda, de su dimensión real. Adviértase que la piedad hacia Cristo puede quedar obscurecida inadecuadamente frente a los santos y la Virgen, que son titulares de muchas más cofradías, ermitas o iglesias, y sus fiestas objeto de voto, precisamente porque ya de por sí los misterios de la Encarnación y la Pasión son centrales en la religiosidad y en la liturgia: mientras hay que buscar santos intercesores y protectores, se cuenta de base con la Redención y se tributa culto a Cristo en las fiestas más importantes del año litúrgico. De modo que, como en otros lugares, no hay por qué negar que al final del Medievo aquí triunfara la piedad patética hacia Cristo sufriente, aunque sería algo más tarde cuando cristalizara en hermandades pasionistas, penitenciales y disciplinantes. El supremo sacrificio del Hijo de Dios hecho hombre como víctima ofrecida por los hombres al Padre aparece incorporado perfectamente en la mentalidad religiosa de estas gentes. Derivando, además, a una sensibilidad piadosa hacia los dolores de la Pasión (afectividad hacia la Cruz); pero sin olvidar el sentido teológico del Sacrificio (alegoría del Cordero).

Ahora bien: el sentido profundo de la devoción a la Pasión en la interioridad espiritual de los cristianos del Campo de Calatrava es algo imposible de determinar. Desde luego, el Jesucristo que se les presenta y conocen no es el Jesús evangélico objeto de imitación, sino ante todo el Salvador. Quedamos sin saber hasta qué punto en el fiel que contempla a su Señor crucificado y doliente existe conciencia de «co-pasión» y aspira a compartir su dolor, o más bien lo que experimenta es un sentimiento religioso, más o menos intenso, de asistir a la obra maravillosa de la Salvación por un Dios que ofrece un consuelo tan definitivo a la Iglesia porque Él mismo sufre en lugar de los hombres ${ }^{138}$.

Convendría reparar en la contradicción que supone defender el protagonismo tardomedieval de una piedad afectiva para con Cristo, Dios Hombre, encarnado, dolorido y partícipe del dolor humano, al que se unen los devotos para

137 1537. AHN, OO.MM., Cjo., Leg. 6.079, n. 3, f. 105v.

138 No habría tanto dramatismo en el culto a la Pasión; la aflicción no es tanto la del hombre, sino la de Dios. Es la idea de G. LoBrichon, La religion des laïcs en Occident. XIe-XVe siècles, pp. 198199. 
cooperar en la Redención, y por otra parte, sostener que en esta época a los fieles sólo se les pedía conocer los rudimentos de la fe y cumplir los mandamientos, en el marco de una concepción «objetivista» de la religión (las prácticas por sí bastan para salvarse $)^{139}$. ¿Cuál será el papel de Jesucristo, entonces, en la mentalidad religiosa? Se ha dicho que al final del Medievo Cristo oscureció la presencia del Padre y del Espíritu Santo hasta casi reducir la Trinidad a una sola Persona ${ }^{140}$. Pero esto no está tan claro en las prescripciones diocesanas ni, en nuestro caso, en las de los visitadores calatravos: el argumento recurrente y fundamento de sus mandatos es el servicio de Dios y su honra. El servicio de Dios es también la palanca para incentivar la caridad de las cofradías asistenciales en sus hospitales del Campo de Calatrava. Nunca se alude a la identificación con la caridad del propio Cristo ni menos a la identificación de los pobres con Cristo como motivo para atenderlos ${ }^{141}$. Y desde luego, las nociones espirituales de Cristo esposo del alma o amigo (como querían Ruysbroeck, los Amigos de Dios, la Devotio Moderna), o Cristo sacerdote, se reservan a los espíritus más cultivados. La religión común del fin del Medievo es conformista y clericalizada y más tendente al individualismo que a la profundización.

¿Cómo podría ser visto Cristo sufriente, en concreto? «Las almas más interiores eran inducidas... a entrar en la intimidad de la Pasión» ${ }^{142}$, pero tal vez los cristianos corrientes miraban en el crucificado sobre todo al Salvador que tranquilizaba su angustia ante la condenación eterna. Probablemente ahí esté la clave. No parece inoportuno conceder que el mínimo común denominador de las tendencias espirituales del final del Medievo, en el que coincidían los místicos y los cristianos sencillos, era la fuerza de esta idea poderosa y eficaz: Cristo era ante todo el Salvador, el crucifijo «se convirtió en una imagen de adoración» ${ }^{143}$ y la cruz en sí era «investida por un poder espiritual directamente contenido en el objeto» ${ }^{144}$. Se ha dicho que hacia el final del siglo XV «el cristianismo se reduce a una soteriología» ${ }^{145}$, y ello no es incompatible con la devoción a Cristo doloroso. En toda Europa, en los reinos hispánicos, y en las villas y lugares arriba indicados, parece confirmarse el afán de revivir y apropiarse sensorialmente los misterios más dramáticos de la Salvación realizada por Cristo, dentro

139 É. Delaruelle, E.-R- Labande y P. Ourliac, La crisis conciliar. La vida religiosa del pueblo cristiano [1378-1449], p. 300.

140 Cristo es llamado Padre; e incluso, aunque minoritariamente, Madre.-Ibidem, p. 174.

141 R. TORRes Jiménez, Religiosidad popular en el Campo de Calatrava. Cofradías y hospitales al final de la Edad Media, Ciudad Real, 1989, por ejemplo en las recapitulaciones de la p. 159.

142 É. Delaruelle, E.-R- Labande y P. Ourliac, La crisis conciliar. La vida religiosa del pueblo cristiano [1378-1449], p. 175.

143 É. Palazzo, Liturgie et société au Moyen Âge, p. 174.

144 Ibidem, p. 175.

145 É. Delaruelle, E.-R- Labande y P. OuRliac, La crisis conciliar. La vida religiosa del pueblo cristiano [1378-1449], p. 174. 
y fuera del un marco litúrgico. Pero parece que debe relativizarse la afirmación rotunda de un cristocentrismo radical por encima de la devoción a los santos y a la Virgen; es más adecuado hablar de cambios titubeantes, y no lineales, en la espiritualidad de los creyentes medios. El culto interiorizado de compasión a los dolores de Cristo coincidiría con el sentido difuso de la divinidad y la obligación del hombre de servir a Dios, acompañados de la falta de una conciencia nítida sobre la especificidad esencial del cristianismo, la encarnación de Dios en la humanidad. Los intercesores eran necesarios, y la cruz siempre fue lo que la liturgia del Viernes Santo ha cantado y sigue cantando durante el ritual de su adoración: «el árbol del que estuvo clavada la salvación del mundo». 